\title{
1 New skeletal tuberculosis cases in past populations from Western 2 Hungary (Transdanubia)
}

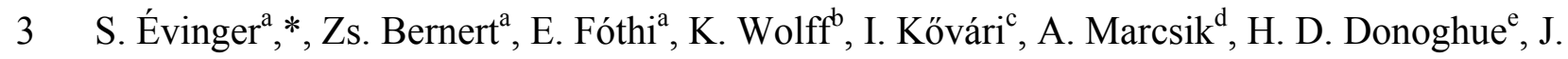

$4 \mathrm{O}^{\prime} \mathrm{Grady}^{\mathrm{e}}{ }^{\mathrm{K}}$,. K. Kiss ${ }^{\mathrm{f}}$, T. Hajdu ${ }^{\mathrm{g}}$

$6 \quad{ }^{a}$ Department of Anthropology, Hungarian Natural History Museum, Budapest, H-1083, Ludovika

7 square 2., Hungary

8 bepartment of Forensic Medicine Semmelweis University, Budapest, H-1091, Üllői str. 93.

9 Hungary

10 'Department of Archaeology, Herman Ottó Museum, Miskolc, H-3529, Görgey Artúr str. 28.,

11 Hungary

$12{ }^{\mathrm{d}}$ Retired associate professor, University of Szeged, H-6771 Szeged, Mályva str.,23., Hungary

$13{ }^{\mathrm{e}}$ Centre for Infectious Diseases and International Health, Department of Infection, University

14 College London, UK W1T 4JF Windeyer Building, 46, Cleveland Street, London, United

15 Kingdom

16 f Department of Diagnostic Radiology and Oncotherapy, Semmelweis University, Budapest, H-

17 1082, Üllői str. 78/a., Hungary

$18{ }^{\mathrm{g}}$ Department of Biological Anthropology, Eötvös Loránd University, Budapest, H-1117,

19 Pázmány Péter str. 1/C., Hungary

22 Abbreviated title: Tuberculosis in ancient Transdanubia, Hungary

23 Corresponding author: Sándor Évinger, tel.: 00-36-1-3138617, e-mail: evinger@nhmus.hu 
2 The distribution, antiquity and epidemiology of tuberculosis (TB) have previously been studied in 3 osteoarchaeological material in the eastern part of Hungary, mainly on the Great Plain. The 4 purpose of this study is to map the occurrence of skeletal TB in different centuries in the Western 5 part of Hungary, Transdanubia, and to present new cases we have found. Paleopathological

6 analysis was carried out using gross observation supported by radiographic and molecular

7 methods. A large human osteoarchaeological sample $(\mathrm{n}=5684)$ from Transdanubian

8 archaeological sites ranging from the 2 nd to the 18 th centuries served as a source of material.

9 Spinal TB was observed in seven individuals (in three specimens with Pott's disease two of

10 which also had cold abscess) and hip TB was assumed in one case. The results of DNA for

11 Mycobacterium tuberculosis were positive in seven of the eight cases identified by

12 paleopathology, and negative in the assumed case of hip TB. However, the molecular results are

13 consistent with highly fragmented DNA, which limited further analysis. Based on the present

14 study and previously published cases, osteotuberculosis was found in Transdanubia mainly

15 during the 9th-13th centuries. However, there are no signs of TB in many other 9th-13th

16 centuries, even in those that lie geographically close to those where osteotuberculous cases were

17 found. This may be due to a true absence of TB caused by the different living conditions, way of

18 life, or origin of these populations An alternative explanation is that TB was present in some

19 individuals with no typical paleopathology, but that death occurred before skeletal morphological

20 features could develop. 


\section{Introduction}

2 Tuberculosis (TB) and other infectious diseases have been a major natural selective factor in

3 human evolution and have deeply influenced population history and civilization (Marcsik et al.,

4 2006; Ubelaker, 1996). It affects all ages and ranges in severity from latent to hyperacute (Kelley

5 and El-Najjar, 1980). TB is responsible for more deaths than any other bacterial disease (Kelley

6 and El-Najjar, 1980; Vincent and Gutierrez, 1999). It is caused by a group of closely related

7 bacterial species termed the Mycobacterium tuberculosis complex, which are obligate pathogens.

8 The principal cause of human TB is Mycobacterium tuberculosis. Mycobacterium bovis is the

9 main cause of TB in other animal species. Human TB is principally transmitted via infectious

10 aerosols released from the lungs of an infected person who has pulmonary disease. M. bovis can

11 be acquired from animals by direct contact, or the ingestion of infected meat or dairy products

12 (Aufderheide and Rodríguez-Martín, 1998; O’Reilly and Daborn, 1995; Vincent and Gutierrez, 13 1999).

14 With rare exceptions, skeletal TB is a secondary infection from either the lungs or the lymph

15 nodes, the results of limited hematogenous dissemination (Panuel et al., 1999). The great majority

16 of statistical analyses indicate that the three major sites of skeletal TB are the vertebral column

17 (spinalTB), the hip, and the knee (Panuel et al., 1999). In general, the joints of the lower

18 extremities are affected much more often than are the joints of the upper extremities (Steinbock, 19 1976).

20 Skeletal TB is found mostly in the lower thoracic and upper lumbar vertebrae involving two to 21 four vertebrae (Brothwell, 1963; Ortner, 2003). The central and anterior portions of the vertebral 22 bodies are the most common sites (Aufderheide and Rodríguez-Martín, 1998; Ortner, 2003). The 23 infection rarely involves the transverse processes, pedicles, lamina, or spinous processes of the vertebrae (Aufderheide and Rodríguez-Martín, 1998). As a result of the extensive trabecular and cortical destruction (without new bone formation), collapse of the involved vertebral bodies occurs (Panuel et al., 1999). The unequal collapse results in an angular posterior deformity or kyphosis (Aufderheide and Rodríguez-Martín, 1998; Ortner, 2003). A common complication of vertebral tuberculosis is the formation of unilateral or bilateral paravertebral abscess that can be accompanied by an associated fistula (Aufderheide and Rodríguez-Martín, 1998; Ortner, 2003).

Regarding the differential diagnosis, many conditions closely resemble spinal TB: e.g. compression fractures, pyogenic osteomyelitis, blastomycosis, brucellosis, actinomycosis, 
1 Paget's disease, neoplasms, metastatic carcinoma, etc (Aufderheide and Rodríguez-Martín, 1998;

2 Ortner, 2003).

3

4 Paleopathological research of skeletal TB in Hungary

5 Paleopathological studies of the distribution, antiquity and epidemiology of TB have

6 previously been based on osteoarchaeological material from the eastern part of Hungary, mainly the Great Plain (Donoghue et al., 2005; Haas et al., 1999; Marcsik et al., 2002, 2006, 2007; Pálfi and Marcsik, 1999). In addition, there is one description of a severe case of skeletal TB (spinal

9 TB and spina ventosa), which originated on the Great Plain (Bačka-Topola) at a site now in modern Serbia (Farkas et al., 1976).

The Dominician Church of Vác, a town near Budapest, is very important, because of the large number of spontaneously mummified persons that were buried there mainly in the 18th century.

13 In total, 265 specimens from coffins and another approximately 46 remains from an ossuary were

14 found, and morphological and radiological studies revealed cases of spinal TB (Pott's disease and other vertebral destructions) among them. Based on molecular analysis, the prevalence of TB was very high (Donoghue et al., 2009; Fletcher et al., 2003a, 2003b; Pálfi et al., 2004; Pap et al., 1999, 2002, 2008; Spigelman et al., 2006).

In Western Hungary (Transdanubia), only isolated examples have been reported. An adult spinal TB case was described by Merczi (2001), and another adult case suggestive of spinal TB, dated to the 16th century, reported by Éry (1982). The Székesfehérvár burial-ground includes skeletal material dated to different centuries, and spinal TB was diagnosed in four cases (Donoghue et al., 2008; Éry et al., 2008a, 2008b). Another case of spinal TB was described in material from Zalavár-Vár (Acsádi et al., 1962).

The purpose of the current study was to map the occurrence of skeletal TB in different centuries in western Hungary, Transdanubia, and to present new cases we have found.

\section{Materials and methods}

A large skeletal sample $(\mathrm{n}=5684)$ served as a source of material for the paleopathological and general anthropological investigations (Table 1 and Fig. 1).

The skeletal materials are housed at the Department of Anthropology, Hungarian Natural

31 History Museum, Budapest, and at the Balaton Museum, Keszthely, Hungary. 
Paleopathological analysis was based on gross observation. For possible TB cases radiographic and molecular methods were used.

3 Due to the variation in osteoarchaeological skeletal preservation, it was not possible to apply statistical methods to characterise the distribution of skeletal tuberculous lesions. These lesions can be localised in different parts of the bones, but soil acidity and other forms of postmortem

6 destruction can damage osteoarchaeological material, and obscure any possible evidence of disease. Furthermore, the bones of infants are often missing, therefore the exact prevalence of the

8 disease in different populations and time periods cannot be presented.

\section{Molecular analysis of DNA for the Mycobacterium tuberculosis complex}

Possible cases of skeletal TB, defined according to skeletal morphological changes, were examined for the presence of DNA from the M. tuberculosis complex. Recommended protocols for ancient DNA (aDNA) work were followed (O'Rourke et al., 2000, Taylor et al., 2010), with separate rooms and equipment for different stages of the process. A small quantity (50-100 mg) of each sample was crushed in a sterile pestle and mortar and added to $400 \mu$ of Proteinase $\mathrm{K} /$ EDTA. The slurry was incubated at $56^{\circ} \mathrm{C}$ (Donoghue et al., 2005), and mixed on a bead beater daily. When the sample was solubilized, it was split and one aliquot treated with $40 \mu 1$ of $^{0.1 \mathrm{~mol}^{-}}$ ${ }^{1}$ of $N$-phenacylthiozolium bromide (PTB), to cleave any covalent cross-links thus enabling DNA strand separation and amplification (Poinar et al., 1998). Sample tube contents were transferred into separate $9 \mathrm{ml}$ tubes of NucliSens ${ }^{\circledR}$ (bioMérieux) lysis buffer containing $5 \mathrm{~mol}^{-1}$ guanidium thiocyanate and incubated for $1-3$ days at $56^{\circ} \mathrm{C}$. To complete the disruption of bone and any mycobacterial remnants, samples were boiled, then snap-frozen in liquid nitrogen and thawed in a $65{ }^{\circ} \mathrm{C}$ waterbath. This procedure was repeated twice. Sample tubes were centriguged at $5000 \mathrm{~g}$ for 15 mins at $5^{\circ} \mathrm{C}$ and the supernates carefully removed into clean, sterile tubes. DNA was captured by adding $40 \mu \mathrm{l}$ silica suspension (NucliSens ${ }^{\circledR}$ ) and mixing on a rotator wheel for 1 hour. Tube contents were centrifuged and silica pellets washed once with wash buffer (NucliSens ${ }^{\circledR}$ ), twice with $70 \%(\mathrm{v} / \mathrm{v})$ ethanol $\left(-20^{\circ} \mathrm{C}\right)$ and once with acetone $\left(-20{ }^{\circ} \mathrm{C}\right)$. After drying in a heating block, DNA was eluted using $60 \mu$ l elution buffer $\left(\right.$ NucliSens $\left.{ }^{\circledR}\right)$, aliquoted and used immediately or stored at $-20^{\circ} \mathrm{C}$. Silica supernates $(500 \mu \mathrm{l})$ from PTB-negative samples were also collected from the $9 \mathrm{ml}$ tubes of lysis buffer, and the $2.0 \mathrm{ml}$ screw-capped Eppendorf tubes used to wash the silica. After chilling at $5^{\circ} \mathrm{C}$, supernates were mixed vigorously for $20 \mathrm{sec}$ with $200 \mu \mathrm{l}$ of Protein 
1 Precipitation Solution (SLS Ltd, UK) and centrifuged for 3 min at 10,000 g. Any pellet was

2 discarded and $600 \mu 1$ isopropanol $\left(-20^{\circ} \mathrm{C}\right)$ added to $550 \mu 1$ of each supernate. Tubes were mixed

3 by inversion 50 times and spun $3 \mathrm{~min}$. Supernates were discarded and tubes washed once with

$4500 \mu 170 \%$ ethanol $\left(-20^{\circ} \mathrm{C}\right)$. After draining, tubes were dried in a heating block. Any precipitated

5 DNA was re-hydrated with $60 \mu 1$ elution buffer $\left(\right.$ NucliSens $^{\circledR}$ ), aliquoted and used immediately or

6 stored at $-20^{\circ} \mathrm{C}$. Negative extraction controls were processed in parallel with the test samples.

\section{DNA amplification and detection}

8 Two specific regions of the M. tuberculosis complex were targeted in the repetitive elements

9 IS6110 and IS1081. Initially primers were used which give PCR products of $129 \mathrm{bp}$ (Eisenach et

10 al., 1990) and 113 bp (Taylor et al., 2003), respectively. Subsequently, specific M. tuberculosis

11 complex primers and fluorescent probes were designed, to enable shorter DNA fragments to be

12 detected (Table 2). The PCR mix included 2 mM BSA to reduce PCR inhibition (Abu Al-Soud

13 and Rådström, 2000; Forbes and Hicks, 1996), $2.0 \mathrm{mM} \mathrm{MgCl}_{2}$ and annealing was at $60^{\circ} \mathrm{C}$. A hot-

14 start Taq polymerase was used to minimise non-specific primer and template binding. Negative

15 DNA extraction and PCR controls were processed alongside the test sample. Amplification was

16 performed in a final volume of $25 \mu 1$ using conventional PCR, or the Corbett Research

17 RotorGene 3000 real-time platform (Taylor et al., 2007). PCR product from conventional PCR

18 was detected by gel electrophoresis using 3.0\%(w/v) NuSieve 3:1 agarose gel (FMC Bioproducts,

19 Flowgen $)$ in TBE buffer $\left(0.09 \mathrm{~mol}^{-1}\right.$ Tris-borate and $0.002 \mathrm{~mol}^{-1}$ EDTA) at 8.8 volts $\mathrm{cm}^{1}$ for 80

20 min. Amplified DNA was visualized by ethidium bromide staining exposed under ultraviolet

21 light and was recorded with a Polaroid camera. SYBR Green was initially included in the Real-

22 Time PCR mix to directly visualize double-stranded DNA via fluorescence and the $T_{m}$

23 determined by a subsequent melt analysis (Taylor et al., 2007). The specific probes enabled direct

24 observation of specific amplicons and the determination of cycle threshold $(\mathrm{Ct})$ indicated relative

25 concentration of template. When sequencing was undertaken, PCR amplicons were separated on

26 low melting point $2 \%$ agarose gels in TAE buffer. Bands of the anticipated molecular weight

27 were excised under ultraviolet light with single-use sterile scalpel blades, prepared and

28 sequenced, using a commercial DNA purification kit (Anachem Ltd GeneClean ${ }^{\circledR}$ II) and

29 sequencing service (Cogenics Ltd, Takely, Essex, UK). 


\section{Results}

2 Based on skeletal morphological changes, eight cases of skeletal TB were identified. These

3 new cases are described in detail below.

5 Case reports

6 Site: SZEKSZÁRD-Tószegi dülő (6th-7th centuries)

7 Grave no.: 1074. object (6th-7th centuries)

8 Sex: male (25-30 years)

9 On the left side, the acetabulum and the head of femur have partly disappeared due to a 10 disease process; subluxation and osteoporosis of the femur and the ilium are visible, and evidence 11 of severe inflammation is present on the body of the femur and on the pelvis between the 12 acetabulum and the greater sciatic notch. The acetabulum shows several defects and its articular 13 surface is granular. The margin of the acetabulum is characterised by new bone formation 14 probably representing a healing phase of this tuberculous infection. The lateral surface of the 15 ilium shaft is eroded (after pass-formation?) (Fig. 2).

16 Diagnosis: probable hip tuberculosis, diagnostic option include other infectious processes

17 DNA for Mycobacterium tuberculosis complex: negative

Site: ZALAVÁR-Vársziget-Hadrianus templom (9th-13th centuries) Grave no.: 135/01 (9th century)

21 Sex: - (juvenile, 15-17 years)

22 There are multiple destructive foci in the body of the second and third lumbar vertebrae; the body of L2 is partially missing (Fig. 3). The right auricular surfaces of the sacrum and the ilium are fused. Beside the fusion, there is a large perforation with a diameter of $\sim 33 \mathrm{~mm}$ on the ala of ilium. Its surface is very rough and shows signs of inflammation. Similar severe destructions can be seen on the medial and lateral surfaces of the ala of ilium due to inflammatory processes (Fig. 4). On the radiograph showing the hip area, the large perforation can be demonstrated, and osteosclerosis is present at the area of the fusion (Fig. 5).

29 Diagnosis: spinal tuberculosis in the lumbar vertebrae, with prevertebral cold abscess DNA for Mycobacterium tuberculosis complex: positive for IS6110 (75 bp) 
Site: ZALAVÁR-Vársziget-Hadrianus templom (9th-13th centuries)

2 Grave No.: 50/01 (9th century)

3 Sex: male (22-24 years)

4 There are multiple small and larger confluent cavities with severe destruction on the anterior

5 parts of the third and fourth lumbar vertebral bodies. Much of their spongious substance has

6 disappeared mostly in the dorsal direction. The tuberculous process is localized only in L3-4 (Fig.

$76)$.

8 Diagnosis: probably spinal tuberculosis

9 DNA for Mycobacterium tuberculosis complex: positive for IS1081 (113 bp)

11 Site: ZALAVÁR-Vársziget-Hadrianus templom (9th-13th centuries)

12 Grave No.: 39/02 (9th century)

13 Sex: female (30-40 years)

14 There are multiple destructive loci in the spine. Th1-3 are fused probably as a consequence of

15 a fracture on Th2. Fused vertebra formed from Th7-8, with the body height of Th8 being normal,

16 but with the body height of Th7 being decreased. The inferior surface of the body of Th8 and the

17 superior surface of Th9 have multiple larger and smaller cavities. Lytic focuses can be seen in the

18 vertebral body of L1, and the L2 and L3 vertebrae have fused (Figs. 7-10).

19 Diagnosis: spinal tuberculosis (it is probable that the tuberculous process involved two sites: Th7-

$20 \quad 8$ and L1-3)

21 DNA for Mycobacterium tuberculosis complex: positive for IS6110 (75 bp) and IS1081 (113 bp)

\section{Site: ZALAVÁR-Vársziget-Kápolna (11th-13th centuries)}

24 Grave No.: 17/03 (11th-13th centuries)

25 Sex: - (juvenile, 15-16 years)

26 The anterior portion of the vertebral bodies is seriously affected. An angular kyphosis (Pott's

27 disease) is produced by the unequal collapse of Th10-11. There is a fusion from Th8 to L2. Pott's

28 deformity is stabilized by new bone formation due to healing (Figs. 11-12).

29 Diagnosis: spinal tuberculosis (advanced Pott's disease)

30 DNA for Mycobacterium tuberculosis complex: positive for IS6110 (75 bp) 
2 Grave No.: 32/02 (11th-13th centuries)

3 Sex: male (35-40 years)

4 Several vertebrae show tuberculous destruction and collapse. There are three fused vertebral

5 "blocks" in the spine (Th1-4, Th5-11, Th12-L2). A severe angular kyphosis is produced by the

6 tuberculous collapse of Th8-10 (Fig. 13). On lateral radiograph advanced osteosclerosis is shown

7 at the angulation of the spine (Fig. 14).

8 Diagnosis: spinal tuberculosis (advanced Pott's disease)

9 DNA for Mycobacterium tuberculosis complex: positive for IS6110 (75 bp)

11 Site: ZALAVÁR-Vársziget-Kápolna (11th-13th centuries)

12 Grave No.: 74/03 (11th-13th centuries)

13 Sex: male (20-40 years)

14 Fusion of vertebrae can be seen between Th6-8, with the body of Th7 having disappeared. The 15 collapse has resulted in a slight gibbus in the infected vertebra (Pott's disease). The gibbus is 16 wedge-shaped and cavities can be seen from anterior and lateral views. Effects of prevertebral 17 cold abscesses can be found on the thoracic vertebrae 8-10 (Fig. 15).

18 Diagnosis: spinal tuberculosis with the sign of cold abscess

19 DNA for Mycobacterium tuberculosis complex: positive for IS6110 (75 bp), weak positive for 20 IS1081 (113 bp)

\section{Site: ZSÁMBÉK - Premontrei templom (11th-18th centuries)}

24 Grave No.: 161 (18th century)

25 Sex: female (50-60 years)

26 The fifth lumbar vertebra is fused with the sacrum. There is a resorption of the L5, and smaller and larger cavities with severe destruction, and resorptive changes can be viewed on the superior

28 surface of the bodies L3-5. There are reactive bone formations on the anterior side of the sacrum

29 (Figs. 16-17). (The lumbar 1-2, cervical and thoracic vertebrae are missing postmortem).

30 Diagnosis: spinal (lumbosacral) tuberculosis

31 DNA for Mycobacterium tuberculosis complex: positive for IS6110 (75 bp) 
In summary, based on morphology, of eight skeletal TBcases, spinal TB was observed in seven individuals, two of them with advanced gibbuses and one with a slight gibbus. In two specimens the signs of cold abscesses were demonstrated. There was one case of probable hip TB from the Szekszárd-Tószegi dülö site, although the morphological changes could be due to an 6 infectious process other than that of TB.

Neither rib, nor endocranial lesions were observed in the above mentioned cases.

\section{Results of molecular examination}

A positive result for the $M$. tuberculosis complex was obtained from two samples, with freshly eluted DNA, using the IS1081 primers that gave a PCR product of the expected size (113 bp) and

$12 \mathrm{~T}_{\mathrm{m}}$ (Figs. 18-19). Although the $113 \mathrm{bp}$ PCR product from sample 50/01 was clearly demonstrable 13 on the gel (Fig. 20), only a partial sequence was obtained (Figs. 21-22). However, no positive 14 results were obtained with other primers for IS1081, nor with the IS6110 primers with target sequences of $123 \mathrm{bp}$. Five samples gave positive results for the shorter IS6110 locus of $75 \mathrm{bp}$. An

\section{Discussion}

The biomolecular investigations were carried out following rigorous protocols for studies of ancient microbial DNA and with plentiful negative extraction and PCR controls. Each extraction was examined in quadruplicate, and extractions were repeated at least once in every case. The specific loci targeted on the insertion elements have a high percentage of guanidine and cytosine bases (IS6110 60-65\% GC and IS1081 68\% GC), which confers enahanced stability due to the additional hydrogen bond in the DNA molecule. DNA specific for the Mycobacterium tuberculosis complex was detected on one or more occasions in seven of the eight cases identified by paleopathology, and negative in another. Five of the seven positive samples only yielded amplified DNA with specific probe and primers for a 75 bp length of the IS6110 insertion element that can have up to 25 copies per bacterial cell in M. tuberculosis, which increases the sensitivity of the assay. These data are consistent with the DNA being in a highly fragmented state, presumably caused by taphonomic changes over the course of time. The IS1081 region is 
1 conclude whether the disease was caused by the human pathogen M. tuberculosis, or by another

2 member of the complex such as Mycobacterium bovis. However, where it has been possible to

3 determine which member of the M. tuberculosis complex was responsible for past cases of

4 archaeological tuberculosis, the overwhelming majority have been caused by the human tubercle

5 bacillus (Donoghue, 2008).

6 Throughout history, skeletal tuberculosis appears to occur sporadically. In Transdanubia, on

7 the basis of the published and presented cases, more osteotuberculosis was observed during the

8 9th-13th centuries (e.g. Zalavár-Vársziget, Székesfehérvár). However, there are no signs of

9 osteotuberculosis in geographically closer regions of Zalavár and Szekszárd in Transdanubia

10 from the same centuries (Table 1 and Figure 1: Kaposvár, Kereki, Esztergályhorváti, two sites at

11 Vörs, Fonyód). Thus we can reach no clear conclusions from such a small number of positive TB

12 cases. It is theoretically possible that these other contemporaneous populations experienced

13 different conditions (e.g. lived in smaller communities than the once densely populated Zalavár,

14 that was a main regional centre at that time), had adopted an alternative lifestyle and/or were of a

15 different origin that reduced their susceptibility to the disease. Alternatively, TB may have been

16 present but without the development of skeletal lesions, as it is estimated that such lesions occur

17 only in $3-5 \%$ of TB cases from the pre-antibiotic era (Resnick and Niwayama 1995). Further

18 investigations should include specimens with no visible lesions to examine this possibility.

19 However, the differential preservation of skeletal remains and the relatively limited number of

20 excavated sites and examinable specimens pose problems in drawing broader conclusions on the

21 paleoepidemiology of historical tuberculosis in this region.

22 According to Roberts and Buikstra (2003) skeletal TB appeared in Hungary at least 1300 years

23 ago. However, an adult spinal tuberculosis case was published from the Roman Period by Merczi

24 (2001) and a case of hypertrophic ostearthropathy, consistent with TB, has been described

25 (Masson et al., 2008) in a Neolithic population from the Great Plain of Southern Hungary from

26 the Late Neolithic tell settlement (Tisza Culture) of Hódmezővásárhely-Gorzsa (4790-4594 BC).

27 Thus, the appearance of osteotuberculosis dates back to even earlier centuries. Based on previous

28 studies, skeletal TB seems to be the most widespread during the 7 th- 8 th centuries, less so during

29 the 10th-11th centuries, and more during the 14th-17th centuries in Hungary (Pálfi and Marcsik

30 1999). The present study expands and contributes to the general knowledge about the occurrence

31 of skeletal TB in past populations in Hungary, and confirms earlier conclusions, that severe 
1 lesions such as the signs of cold abscess and Pott's disease (advanced angular kyphosis) are good

2 indications of TB.

\section{Acknowledgements}

5 We would like to express our sincere thanks to the Deparment of Radiology and Oncotherapy,

6 Semmelweis University, Budapest, Hungary; and to the Department of Infection, Centre for

7 Infectious Diseases and International Health, University College London.

\section{References}

Abu Al-Soud, W., Rådström, P. 2000. Effects of amplification facilitators on diagnostic PCR in

Acsádi, Gy., Harsányi, L., Nemeskéri, J. 1962. The population of Zalavár in the Middle Ages. Acta. Arch. Hung. 14(1-2), 113-141.

Aufderheide, A.C., Rodríguez-Martín, C. 1998. The Cambridge Encyclopedia of Human

$$
\text { Paleopathology. Cambridge University Press, Cambridge. }
$$

Bak, B. 2003. Historical topography of Hungary. Between the Hungarian Conquest and 1950. [In Hungarian.] 2nd edition. História Könyvtár, Monográfiák 9/a. MTA Történettudományi Intézete, Budapest.

Bernert, Zs. 2003. Anthropological analysis of the Avar Period cemetery of Kereki-Homokbánya (Kereki Sand-pit). Annls. hist-nat. Mus. Natn. Hung. 95, 225-309.

Brothwell, D.R. 1963. Digging up bones. British Museum, London.

Donoghue, H.D. 2008. Palaeomicrobiology of tuberculosis. In: Raoult, D., Drancourt, M. (Eds.) Paleomicrobiology - Past Human Infections. Springer-Verlag GmbH., Berlin-Heidelberg, pp. 75-97.

Donoghue, H.D., Marcsik, A., Matheson, C., Vernon, K., Nuorala, E., Molto, J., Greenblatt, Ch., Spigelman, M. 2005. Co-infection of Mycobacterium tuberculosis and Mycobacterium leprae in human archaeological samples - a possible explanation for the historical decline of leprosy. Proc. R. Soc. Lond. B. Biol. Sci. 272, 389-394.

Donoghue, H.D., Spigelman, M. 2008. Examination of Mycobacterium leprae and Mycobacterium tuberculosis DNA in samples I/11, VI/24 and VI/27 of the Székesfehérvár material. [In Hungarian.] In: Éry, K. (Ed.) A Székesfehérvári Királyi Bazilika embertani 
leletei. [Human skeletal remains from the Saint Stephen's Basilica, Székesfehérvár.] Ecclesia Beatae Mariae Virginis Albaeregalis I. Balassi Kiadó, Budapest, pp. 171-174.

Donoghue, H.D., Pap, I., Szikossy, I., Spigelman, M. 2009. Detection and characterization of Mycobacterium tuberculosis DNA in 18th-Century Hungarian adults and children with pulmonatory and extra-pulmonatory tuberculosis [abstract]. In: Programme and Abstracts. 1st

\section{Bolzano Mummy Congress, Mummies and Life Sciences, 2009 March 19-21, EURAC -} Institute for Mummies and the Iceman, Bolzano, Italy, p 24.

Eisenach, K.D., Cave, M.D., Bates, J.H., Crawford, J.T. 1990. Polymerase chain reaction amplification of a repetitive DNA sequence specific for Mycobacterium tuberculosis. J. Infect. Dis. 161, 977-981.

Éry, K. 1982. Balkáni eredetü, török kori népesség csontmaradványai Dombóvár határából. (The osteological remains of a Turkish Period Balkan population in the Vicinity of Dombóvár). A Szekszárdi Béri Balogh Ádám Múzeum Évkönyve 10-11, 225-298.

Éry, K., Marcsik, A., Nemeskéri, J., Szalai, F. 2008a. The skeletal findings from the built-graves (I. group). [In Hungarian.] In: Éry, K. (Ed.) A Székesfehérvári Királyi Bazilika embertani leletei. [Human skeletal remains from the Saint Stephen's Basilica, Székesfehérvár.] Ecclesia Beatae Mariae Virginis Albaeregalis I. Balassi Kiadó, Budapest, pp. 37-119.

Éry, K., Marcsik, A., Szalai, F. 2008b. The skeletal findings from the earth-graves (II-IX. groups). [In Hungarian.] In: Éry, K. (Ed.) A Székesfehérvári Királyi Bazilika embertani leletei. [Human skeletal remains from the Saint Stephen's Basilica, Székesfehérvár.] Ecclesia Beatae Mariae Virginis Albaeregalis I. Balassi Kiadó, Budapest, pp. 119-134. Évinger, S., Bernert, Zs. 2005. Anthropological investigation of the Avar Period cemetery of Kaposvár Road 61, Site No. 26. (Hungary). Annls. hist-nat. Mus. Natn. Hung. 97, 261-319. Farkas, Gy., Marcsik, A., Vékony, L. 1976. Vertebral deformation in the avar skeletal material. Anthropologie 14, 231-233.

Fletcher, H.A., Donoghue, H.D., Holton, J., Pap, I., Spigelman, M. 2003a. Widespread occurrence of Mycobacterium tuberculosis DNA from 18th-19th Century Hungarians. Am. J. Phys. Anthropol. 120, 144-152.

Fletcher, H.A., Donoghue, H.D., Taylor, G.M., Van Der Zanden, A.G.M., Spigelman, M. 2003 b. Molecular analysis of the Mycobacterium tuberculosis from a family of 18 th century Hungarians. Microbiology 149, 143-151. 
Forbes, B.A., Hicks, K.E. 1996. Substances interfering with direct detection of Mycobacterium tuberculosis in clinical specimens by PCR: effects of bovine serum albumin. J. Clin. Microbiol. 34, 2125-2128.

Haas, J.Ch., Zink, A., Molnár, E., Marcsik, A., Dutour, O., Nerlich, G., Pálfi, Gy. 1999.

Molecular evidence for tuberculosis in Hungarian skeletal sample. In: Pálfi, Gy., Dutour, O., Deák, J., Hutás, I. (Eds.) Tuberculosis Past and Present. Tuberculosis Foundation, Golden Book Publisher Ltd., Budapest, pp. 385-391.

Hajdu, T. 2006. Anthropological examination of the human skeletal findings from the Premonstratensian temple of Zsámbék. [In Hungarian.] Master's thesis. Department of Biological Anthropology, Eötvös Loránd University, Budapest.

Kelley, M.A., El-Najjar, M.Y. 1980. Natural variation and differential diagnosis of skeletal changes in tuberculosis. Am. J. Phys. Anthropol. 52, 153-167.

Marcsik, A., Fóthi, E., Hegyi, A. 2002. Paleopathological changes in the Carpathian Basin in the 10th and 11th centuries. Acta. Biol. Szeged. 46, 95-99.

Marcsik, A., Éry, K., Tóth, G., Suskovics, Cs., Targubáné Rendes, K. 2004. Paleopathological alterations. [In Hungarian.] In: Tóth, G. (Ed.). Karoling-kori emlékek. Régészet és Antropológia. [Relics from the Karoling-Age. Archaeology and Anthropology.] Savaria Univ. Press, Szombathely, pp. 85-106.

Marcsik, A., Molnár, E., Szathmáry, L. 2006. The antiquity of tuberculosis in Hungary: the skeletal evidence. Mem. Inst. Oswaldo. Cruz. 101 Suppl. II, S67-71.

Marcsik, A., Molnár, E., Ösz, B. 2007. Bone alterations of specific infectious diseases in historical populations. [In Hungarian.] JATEPress, Szeged.

Masson, M., Molnár, E., Pálfi, Gy., Bartosiewicz, L. 2008. Palaeopathology of a neolithic population from Southern Hungary [abstract]. 17th European Meeting of the Paleopathology Association, August 25-27, 2008, Copenhagen, Denmark. Paleopathology Newsletter Supplement (ISSN 0148-4737), p41-42.

Merczi, M. 2001. Examination of pathological alterations in the Late Roman Age cemetery of Visegrád-Diós. [In Hungarian.] A Wosinsky Mór Múzeum Évkönyve 23, 25-38.

O’Reilly, L.M., Daborn, C.J. 1995. The epidemiology of Mycobacterium bovis infections in animals and man: a review. Tuber. Lung. Dis. 76 (suppl. 1), 1-46. 
O'Rourke, D.H., Hayes, M.G., Carlyle, S.W. 2000. Ancient DNA studies in physical anthropology. Annu. Rev. Anthropol. 29, 217-242.

Ortner, D.J. 2003. Identification of Pathological Conditions in Human Skeletal Remains. 2nd Edition. Academic Press, Amsterdam-Tokyo.

Panuel, M., Portier, F., Pálfi, Gy., Chaumoître, K., Dutour, O. 1999. Radiological differential diagnosis of skeletal tuberculosis. In: Pálfi, Gy., Dutour, O., Deák, J., Hutás, I. (Eds.)

Tuberculosis Past and Present. Tuberculosis Foundation, Golden Book Publisher Ltd., Budapest, pp. 229-234.

Pap, I., Józsa, L., Repa, I., Bajzik, G., Lakhani, S.R., Donoughe, H.D., Spigelman, M. 1999. 1819th century tuberculosis in naturally mummified individuals (Vác, Hungary). In: Pálfi, Gy., Dutour, O., Deák, J., Hutás, I. (Eds.) Tuberculosis Past and Present. Tuberculosis Foundation, Golden Book Publisher Ltd., Budapest, pp. 421-428.

Pap, I., Kustár, Á., Bernert, Zs., Szikossy, I., Donoghue, H.D., Spigelman, M., Hershkovitz, I., Kristóf, L.A., Barta, M.I., Pálfi, Gy. 2002. Paléopathologie rachidienne de deux momies du XVIIIe s. In: Berato, J. (Ed.) Centre Archéologique du Var, 2001.Centre Archéologique du Var, Toulon, France, pp. 40-42.

Pap, I., Spigelman, M., Szikossy, I., Fletcher, H.A., Donoghue, H.D. 2008. Tuberculosis in an 18th century population of Vác, Hungary [abstract]. 17th European Meeting of the Paleopathology Association, August 25-27, 2008, Copenhagen, Denmark. Paleopathology Newsletter Supplement (ISSN 0148-4737), p79.

Pálfi, Gy., Marcsik, A. 1999. Paleoepidemiological data of tuberculosis in Hungary. In: Pálfi, Gy., Dutour, O., Deák, J., Hutás, I. (Eds.) Tuberculosis Past and Present. Tuberculosis Foundation, Golden Book Publisher Ltd., Budapest, pp. 533-539.

Pálfi, Gy., Pap, I., Kristóf, L.A., Szikossy, I., Donoghue, H.D., Spigelman, M., Barta, H.M. 2004. TB in the mummies of the Vác (18-19th centuries, Vác, Hungary) [abstract]. In: Abstracts. V World Congress on Mummy Studies, 2004 September 2-5, Department of Animal and Human Biology, Turin, Italy, p 86.

Poinar, H.N., Hofreiter, M., Spaulding, W.G., Martin, P.S., Stankiewicz, B.A., Bland, H., Evershed, E.P., Possnert, G., Pääbo, S. 1998. Molecular coproscopy: dung and diet of the extinct ground sloth Nothrotheriops shastensis. Science 281, 402-406. 
1 Resnick, D., Niwayama, G. 1995. Osteomyelitis, septic arthritis and soft tissue infection: organisms. In: Resnick D (ed) Diagnosis of bone and joint disorders, W. B. Saunders, 3 Edinburgh, pp 2448-2558.

4 Roberts, C.A., Buikstra, J. 2003. The bioarchaeology of tuberculosis: a global view on a 5 reemerging disease. University Press of Florida, Gainesville, USA.

6 Spigelman, M., Pap, I., Donoghue, H.D. 2006. A death from Langerhans cell histiocytosis and tuberculosis in 18th Century Hungary - what palaeopathology can tell us today. Leukemia 20,

9 Steinbock, T. 1976. Paleopathological diagnosis and interpretation. Bone diseases in ancient 


\section{Figure legends}

2 Figure 1 Sites of the examined skeletal material in the Carpathian Basin - hydrographic map in

3 the 13th century (Bak, 2003)

4 1: Esztergályhorváti, 2: Zalavár (two sites), 3: Vörs (two sites), 4: Kaposvár, 5: Fonyód, 6 :

5 Kereki, 7: Dombóvár, 8: Szekszárd, 9: Daruszentmiklós, 10: Bölcske, 11: Zsámbék, 12: Budapest

6 (four sites)

8 Figure 2 Probable hip tuberculosis (on the left side)

9 (Szekszárd-Tószegi dűlő, male, Object 1074)

11 Figure 3 Spinal tuberculosis in L2-3

12 (Zalavár-Vársziget-Hadrianus templom, juvenile, Grave No.: 135/01)

14 Figure 4 The sign of cold abscess in the hip

15 (Zalavár-Vársziget-Hadrianus templom, juvenile, Grave No.: 135/01)

17 Figure 5 Radiograph shows cold abscess and other lytic destruction, and the fusion in sacroiliac 18 joint

19 (Zalavár-Vársziget-Hadrianus templom, juvenile, Grave No.: 135/01)

21 Figure 6 Erosive changes in lumbar vertebra

22 (Zalavár-Vársziget-Hadrianus templom, male, Grave No.: 50/01)

24 Figure 7 Lateral view of the spine (right side) with lesions at three sites (Th1-3, Th7-8, L1-3)

25 (Zalavár-Vársziget-Hadrianus templom, female, Grave No.: 39/02)

27 Figure 8 Lateral view of the spine (left side) with lesions at three sites (Th1-3, Th7-8, L1-3)

28 (Zalavár-Vársziget-Hadrianus templom, female, Grave No.: 39/02)

30 Figure 9 Radiograph shows the fusion of Th1-3

31 (Zalavár-Vársziget-Hadrianus templom, female, Grave No.: 39/02) 
2 Figure 10 Radiograph shows the fusion of Th7-8 and L1-3

3 (Zalavár-Vársziget-Hadrianus templom, female, Grave No.: 39/02)

5 Figure 11 Pott's disease, angular kyphosis in Th8-L2

6 (Zalavár-Vársziget-Kápolna, juvenile, Grave No.: 17/03)

8 Figure 12 Radiograph shows Pott's disease; angular kyphosis with osteosclerosis in Th8-L2

9 (Zalavár-Vársziget-Kápolna, juvenile, Grave 17/03)

11 Figure 13 Pott's disease; angular kyphosis in Th8-10, and three fused vertebral „,blocks” (Th1-4,

12 Th5-11, Th12-L2)

13 (Zalavár-Vársziget-Kápolna, juvenile, Grave No.: 32/02)

15 Figure 14 Radiograph shows Pott's disease, angular kyphosis in the thoracic region

16 (Zalavár-Vársziget-Kápolna, juvenile, Grave No.: 32/02)

18 Figure 15 Spinal tuberculosis, lateral view, fusion of vertebrae (Th6-8) with slight gibbus,

19 cavities and traces of cold abscess

20 (Zalavár-Vársziget-Kápolna, juvenile, Grave No.: 74/03)

22 Figure 16 Lumbosacral tuberculosis with erosion and cavities

23 (Zsámbék, premontrei templom, female, Grave No.: 161)

25 Figure 17 Lumbosacral tuberculosis with erosion and cavities in the L4

26 (Zsámbék, premontrei templom, female, Grave No.: 161)

28 Figure 18 Real-time PCR of archaeological samples using IS1081 primers.

30 Figure 19 Melt analysis of Real-time PCR products 
1 Figure 20 Gel of purified IS1081 PCR product from sample 50/01 with molecular markers

2 (bright line on the left indicates the $113 \mathrm{bp}$ PCR product)

3

4 Figure 21 Partial DNA sequences from IS1081 PCR products from sample 39/02 and 50/01 5

6 Figure 22 Partial DNA sequences from IS1081 PCR products from sample 50/01

8 Figure 23 Real time PCR with IS6110 probe and primers showing cycling and cycle thresholds from samples 74/03, 39/02, 32/02 with negative extraction and PCR controls 


\section{$1 \quad$ Tables}

2 Table 1 Some basic data of the examined skeletal materials from Transdanubian sites from the

32 2nd to the 18 th centuries

\begin{tabular}{|c|c|c|c|c|c|c|c|}
\hline Site & Century & $\mathrm{N}_{0-20 \text { years }}$ & $\mathrm{N}_{\text {adult }} \mathrm{O}^{-}$ & $\mathrm{N}_{\text {adult } \text { ㅇ }}$ & $\mathrm{N}_{\text {adult }}$ ? & $\mathrm{N}_{\text {total }}$ & Authors \\
\hline $\begin{array}{l}\text { Budapest. II. ker. } \\
\text { Sajka u. 4-6 }\end{array}$ & 2nd-3rd & 2 & 3 & 3 & 1 & 9 & $\begin{array}{l}\text { Hajdu in } \\
\text { preparation }\end{array}$ \\
\hline $\begin{array}{l}\text { Budapest II. ker. } \\
\text { Lajos utca-Cserfa } \\
\text { utca }\end{array}$ & 2nd-3rd & 2 & 2 & 1 & 0 & 5 & $\begin{array}{l}\text { Hajdu in } \\
\text { preparation }\end{array}$ \\
\hline $\begin{array}{l}\text { Budapest III. ker. } \\
\text { Graphisoft park }\end{array}$ & 2nd-4th & 149 & 220 & 220 & 16 & 605 & $\begin{array}{l}\text { Bernert in } \\
\text { preparation }\end{array}$ \\
\hline $\begin{array}{l}\text { Szekszárd- } \\
\text { Tószigeti dủlő }\end{array}$ & 5 th-8th & 519 & 414 & 421 & 30 & 1384 & $\begin{array}{l}\text { Bernert in } \\
\text { preparation }\end{array}$ \\
\hline Dombóvár-Tesco & $\begin{array}{l}\text { 3rd-4th, } \\
16 \text { th- } \\
17 \text { th }\end{array}$ & 8 & 11 & 14 & 0 & 33 & $\begin{array}{l}\text { Pap-Hajdu in } \\
\text { preparation }\end{array}$ \\
\hline $\begin{array}{l}\text { Daruszentmiklós } \\
\text { (lh. F-05) }\end{array}$ & 7-8th & 8 & 6 & 8 & 0 & 22 & $\begin{array}{l}\text { Hajdu in } \\
\text { preparation }\end{array}$ \\
\hline Kaposvár (lh. 26) & 8th & 98 & 73 & 73 & 10 & 254 & $\begin{array}{l}\text { Évinger and } \\
\text { Bernert, } 2005\end{array}$ \\
\hline $\begin{array}{l}\text { Kereki- } \\
\text { Homokbánya }\end{array}$ & 8th & 36 & 64 & 49 & 4 & 153 & Bernert, 2003 \\
\hline $\begin{array}{l}\text { Esztergályhorváti- } \\
\text { Alsóbáránd puszta }\end{array}$ & 9th-10th & 179 & 65 & 75 & 0 & 319 & $\begin{array}{l}\text { Marcsik et al., } \\
2004\end{array}$ \\
\hline Vörs-Papkert B & 8th-11th & 292 & 206 & 202 & 6 & 706 & $\begin{array}{l}\text { Bernert in } \\
\text { preparation }\end{array}$ \\
\hline Vörs-Majori dűlő & 10th & 145 & 122 & 116 & 5 & 388 & $\begin{array}{l}\text { Bernert in } \\
\text { preparation }\end{array}$ \\
\hline $\begin{array}{l}\text { Zalavár-Vársziget- } \\
\text { Hadrianus templom }\end{array}$ & 9th & 154 & 124 & 102 & 1 & 381 & $\begin{array}{l}\text { Évinger in } \\
\text { preparation }\end{array}$ \\
\hline $\begin{array}{l}\text { Zalavár-Vársziget- } \\
\text { Kápolna }\end{array}$ & $\begin{array}{l}11 \text { th- } \\
12 \text { th }\end{array}$ & 55 & 108 & 94 & 6 & 263 & $\begin{array}{l}\text { Wolff-Évinger- } \\
\text { Gyenis in } \\
\text { preparation }\end{array}$ \\
\hline $\begin{array}{l}\text { Bölcske- } \\
\text { Református } \\
\text { templom }\end{array}$ & $\begin{array}{l}13 \text { th- } \\
16 \text { th }\end{array}$ & 31 & 12 & 7 & 5 & 55 & $\begin{array}{l}\text { Pap-Hajdu in } \\
\text { preparation }\end{array}$ \\
\hline $\begin{array}{l}\text { Zsámbék- } \\
\text { Premontrei } \\
\text { templom }\end{array}$ & $\begin{array}{l}12 \text { th- } \\
18 \text { th }\end{array}$ & 135 & 165 & 87 & 7 & 394 & Hajdu, 2006 \\
\hline $\begin{array}{l}\text { Budapest II. ker } \\
\text { Kapás utca }\end{array}$ & $\begin{array}{l}14 \text { th- } \\
16 \text { th }\end{array}$ & 58 & 126 & 64 & 2 & 250 & $\begin{array}{l}\text { Bernert-Évinger- } \\
\text { Hajdu in } \\
\text { preparation }\end{array}$ \\
\hline $\begin{array}{l}\text { Fonyód- } \\
\text { Bézsenypuszta }\end{array}$ & $\begin{array}{l}16 \text { th- } \\
17 \text { th }\end{array}$ & 205 & 168 & 87 & 3 & 463 & $\begin{array}{l}\text { Bernert-Évinger } \\
\text { in preparation }\end{array}$ \\
\hline Total & & 2076 & 1889 & 1623 & 96 & 5684 & \\
\hline
\end{tabular}


1 Table 2. PCR probe and primer sequences used in the biomolecular investigation 2

\begin{tabular}{|c|c|c|c|}
\hline PCR locus & $\begin{array}{l}\text { Primer } \\
\text { name }\end{array}$ & Primer sequence $\left(5^{\prime}-3^{\prime}\right)$ & $\begin{array}{l}\text { Amplicon } \\
\text { size (bp) }\end{array}$ \\
\hline IS6110 & $\mathrm{P} 1$ & CTCGTCCAGCGCCGCTTCGG & \\
\hline IS6110 & P2 & CCTGCGAGCGTAGGCGTCGG & 123 \\
\hline IS6110 & IS-3 & TTCGGACCACCAGCACCTAA & \\
\hline IS6110 & IS-4 & TCGGTGACAAAGGCCACGTA & 92 \\
\hline IS6110 & $\begin{array}{l}\text { FAM6110 } \\
\text { Probe }\end{array}$ & 5'-ACCTCACCTATGTGTCGACCTG-BHQ1-3' & \\
\hline IS6110 & $6110 \mathrm{~F}$ & CACCTAACCGGCTGTGG & \\
\hline IS6110 & $6110 \mathrm{R}$ & TGACAAAGGCCACGTAGG & 75 \\
\hline IS 1081 & $1081 \mathrm{~F} 2$ & CTGCTCTCGACGTTCATCGCCG & \\
\hline IS 1081 & 1081R3 & TGGCGGTAGCCGTTGCGC & 113 \\
\hline IS 1081 & $\begin{array}{l}\text { FAM1081 } \\
\text { Probe }\end{array}$ & 5'-FAM-GGGCTACCGCGAACGCA-BHQ1-3' & \\
\hline IS 1081 & NF & TGATTGGACCGCTCATCG & \\
\hline IS 1081 & NR & CTTGATGGGGGCTGAAGC & 72 \\
\hline
\end{tabular}




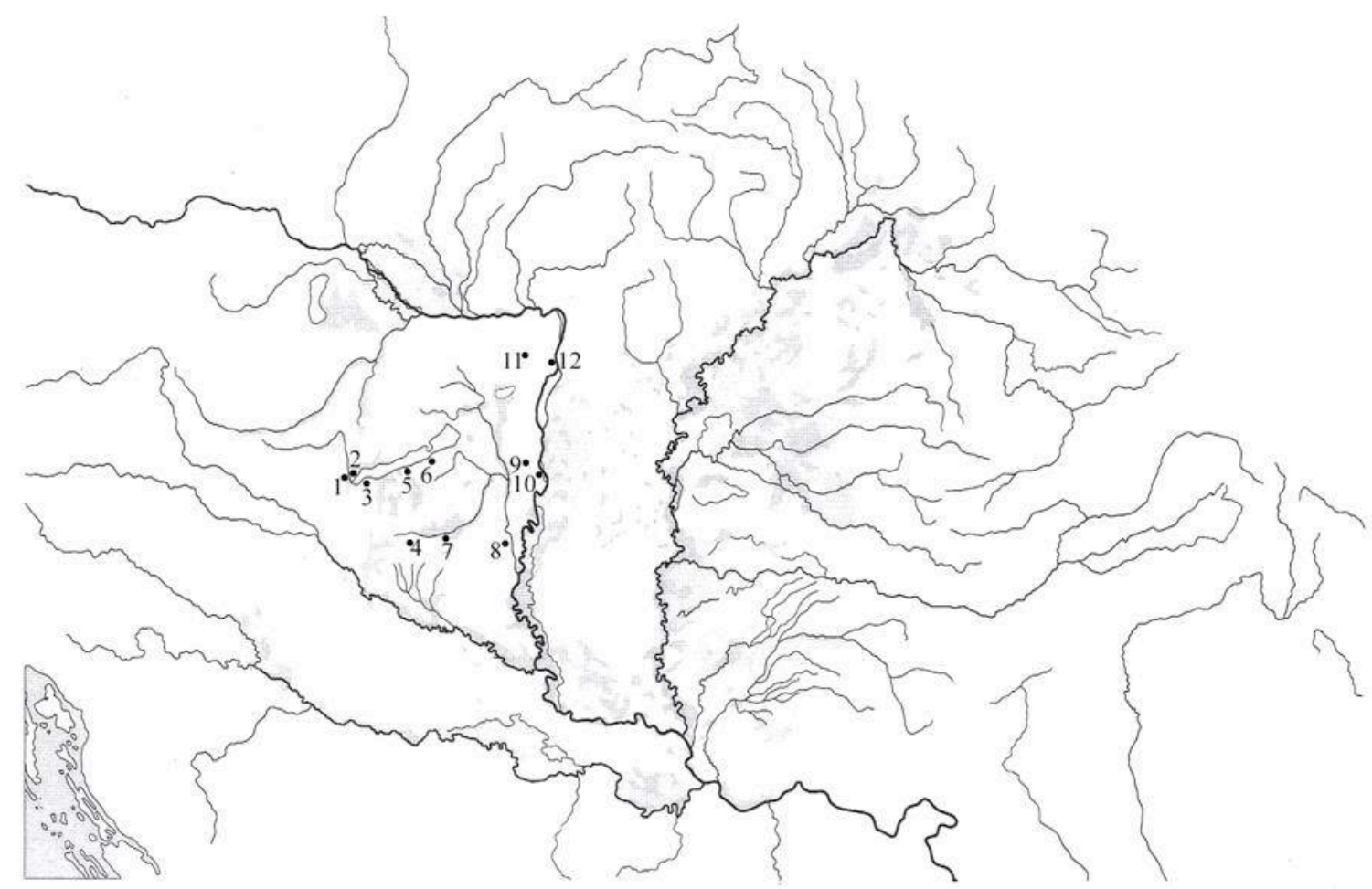

8 Figure 1 Sites of the examined skeletal material in the Carpathian Basin - hydrographic map in 9 the 13th century (Bak, 2003)

10 1: Esztergályhorváti, 2: Zalavár (two sites), 3: Vörs (two sites), 4: Kaposvár, 5: Fonyód, 6:

11 Kereki, 7: Dombóvár, 8: Szekszárd, 9: Daruszentmiklós, 10: Bölcske, 11: Zsámbék, 12: Budapest 12 (four sites)

13 


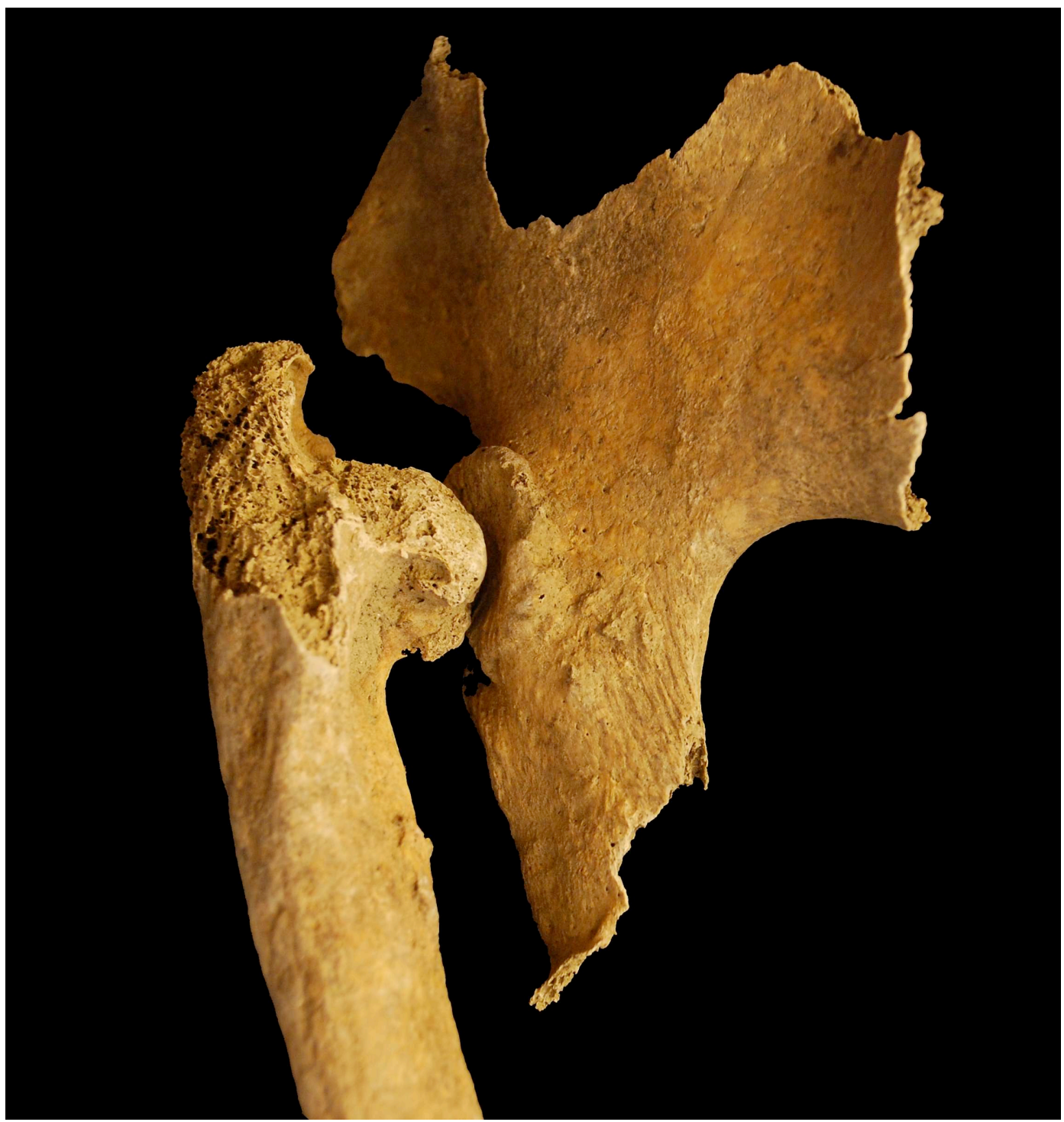

6 Figure 2 Probable hip tuberculosis (on the left side)

7 (Szekszárd-Tószegi dülő, male, Object 1074) 


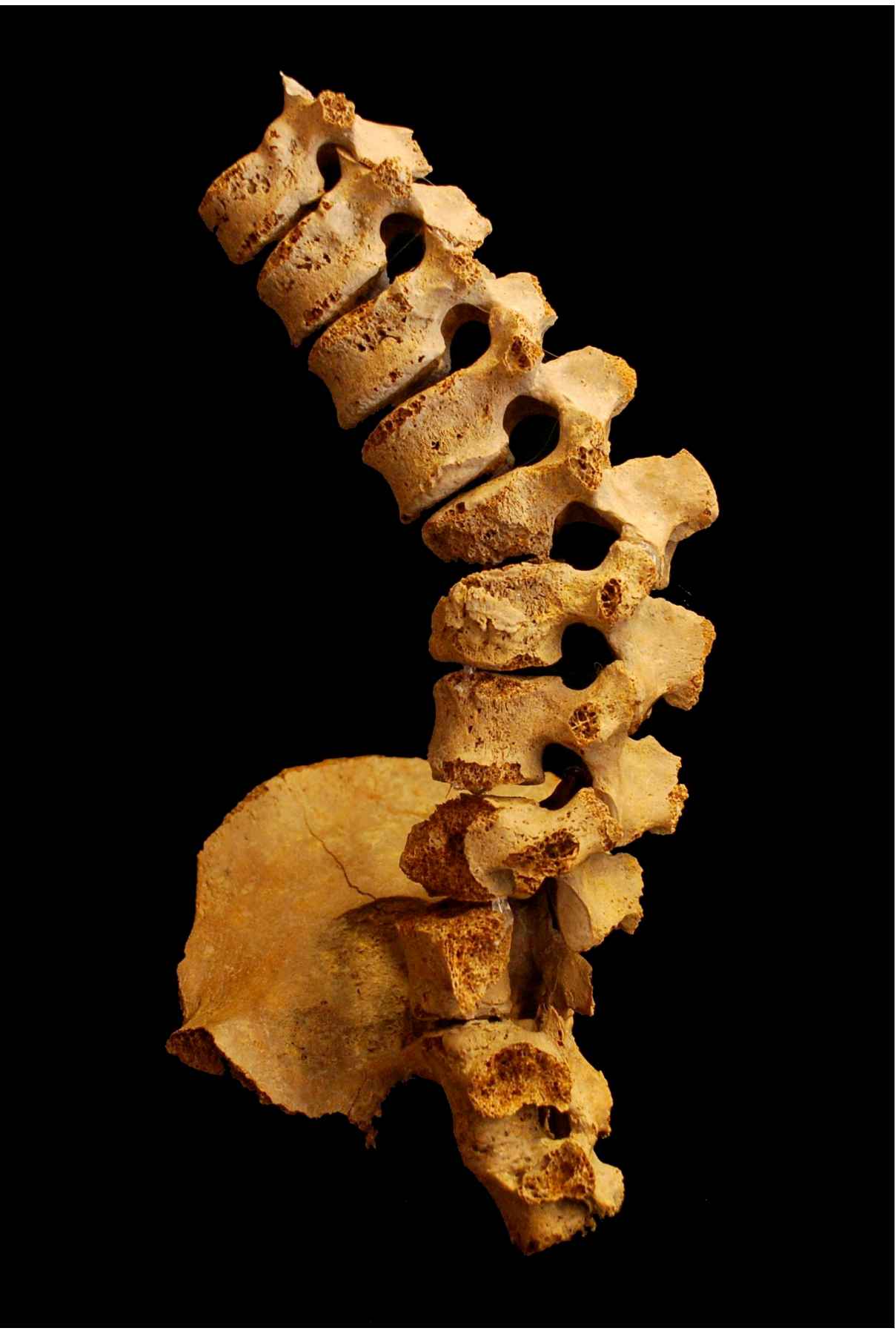

$5 \quad$ Figure 3 Spinal tuberculosis in L2-3

6 (Zalavár-Vársziget-Hadrianus templom, juvenile, Grave No.: 135/01) 


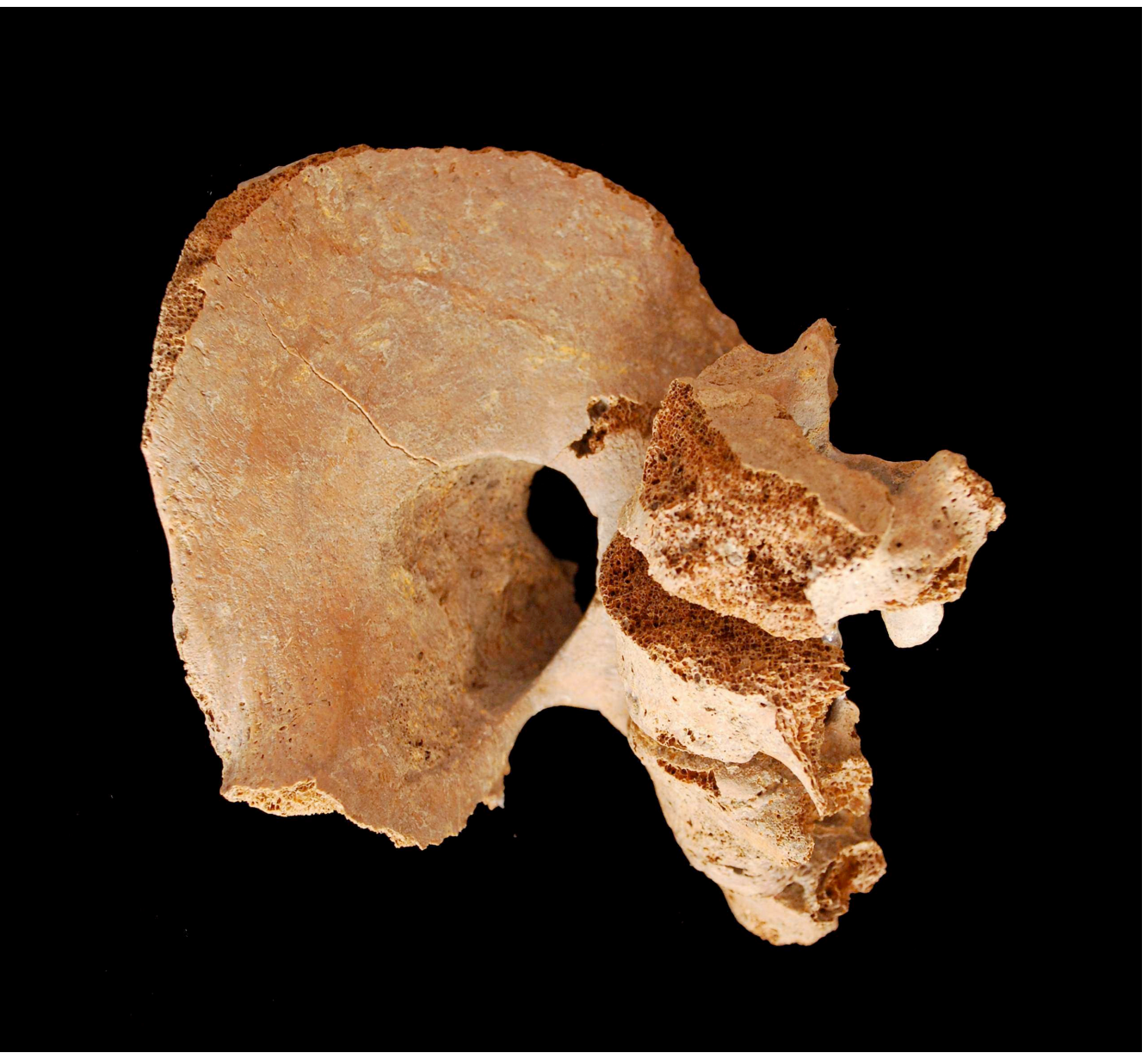

8 Figure 4 The sign of cold abscess in the hip

9 (Zalavár-Vársziget-Hadrianus templom, juvenile, Grave No.: 135/01) 
7 Figure 5 Radiograph shows cold abscess and other lytic destruction, and the fusion in sacroiliac 8 joint

9 (Zalavár-Vársziget-Hadrianus templom, juvenile, Grave No.: 135/01) 


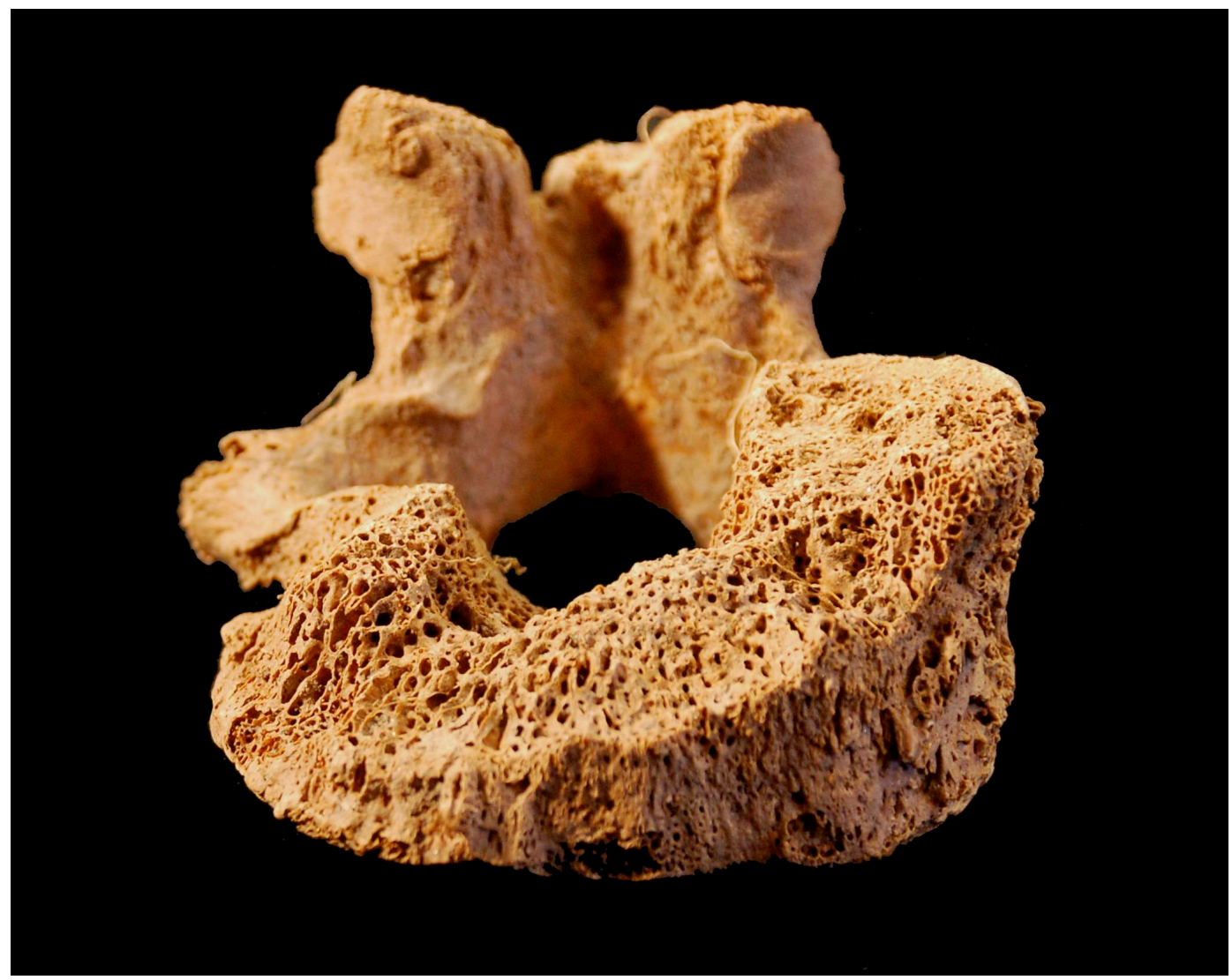

8 Figure 6 Erosive changes in lumbar vertebra

9 (Zalavár-Vársziget-Hadrianus templom, male, Grave No.: 50/01) 


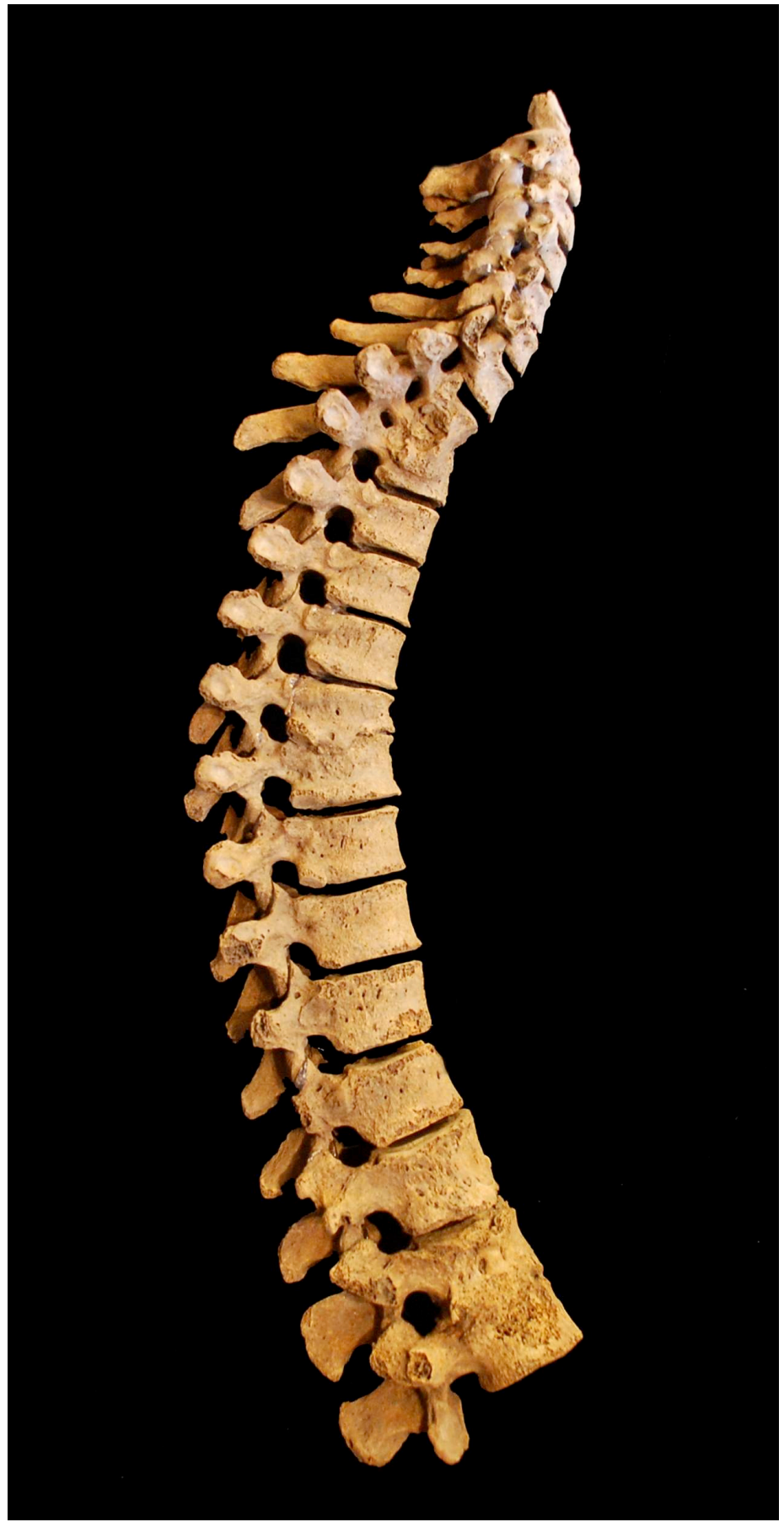

4 Figure 7 Lateral view of the spine (right side) with lesions at three sites (Th1-3, Th7-8, L1-3)

5 (Zalavár-Vársziget-Hadrianus templom, female, Grave No.: 39/02) 


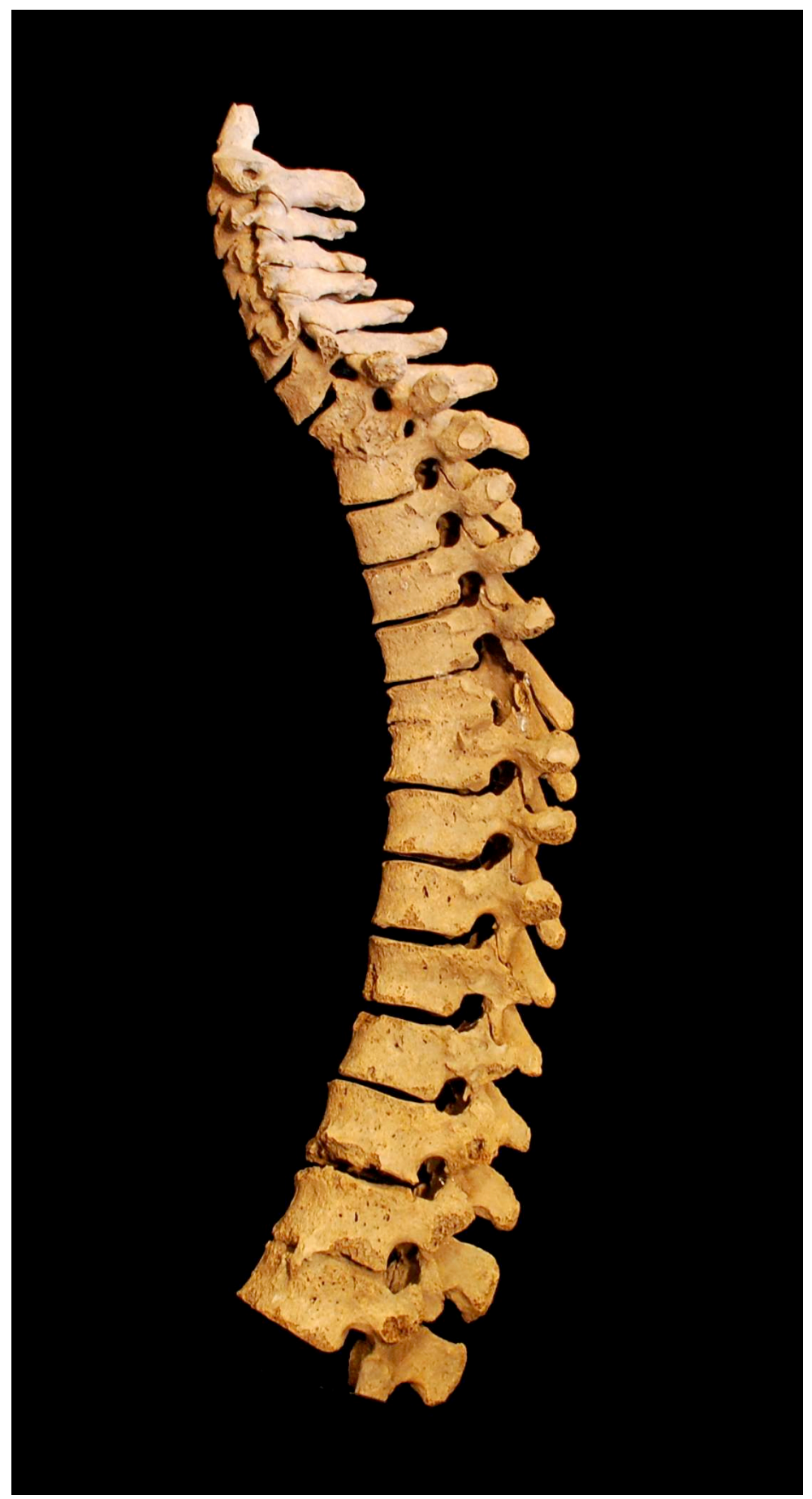

4 Figure 8 Lateral view of the spine (left side) with lesions at three sites (Th1-3, Th7-8, L1-3)

5 (Zalavár-Vársziget-Hadrianus templom, female, Grave No.: 39/02) 
2

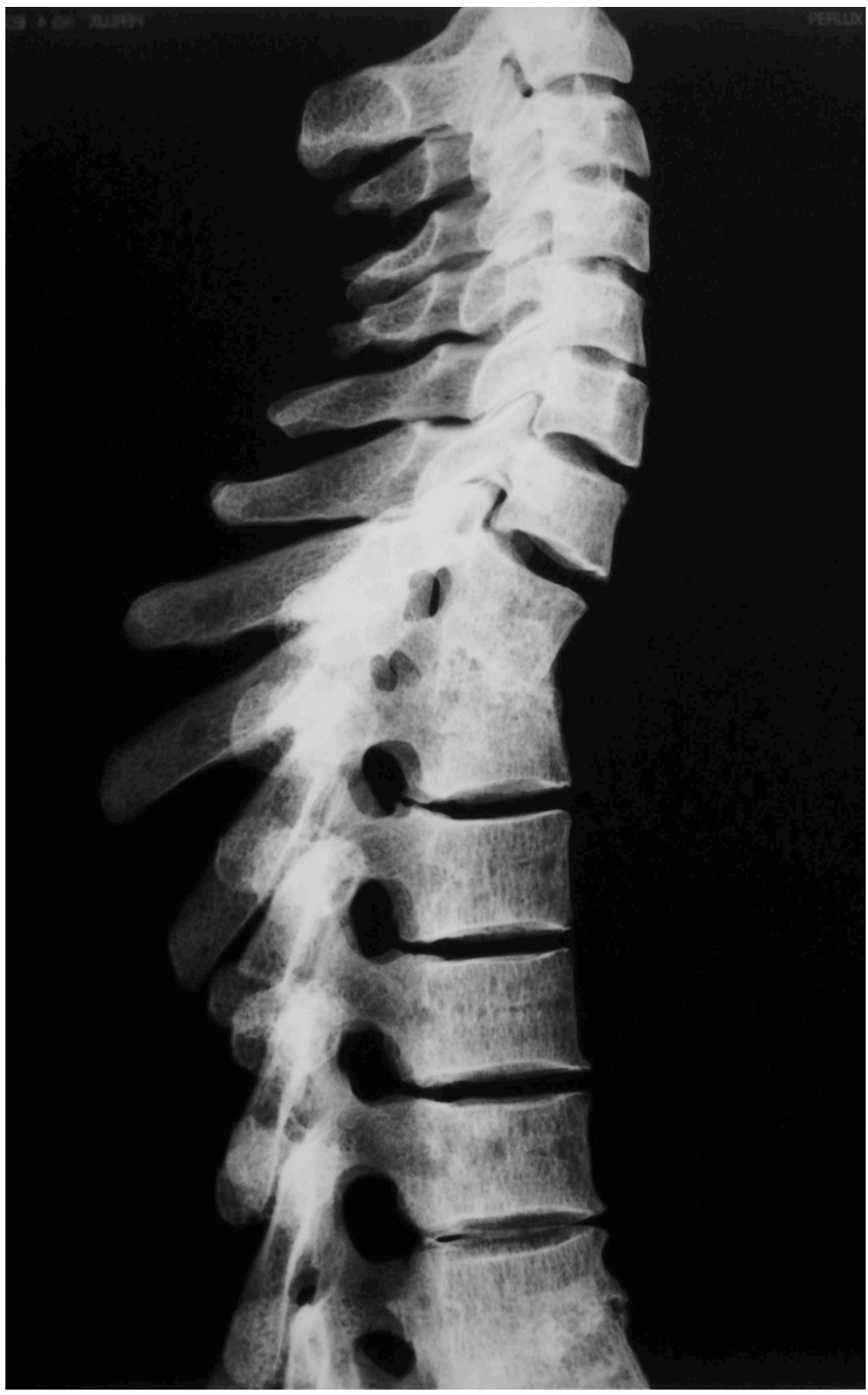

4 Figure 9 Radiograph shows the fusion of Th1-3

5 (Zalavár-Vársziget-Hadrianus templom, female, Grave No.: 39/02) 


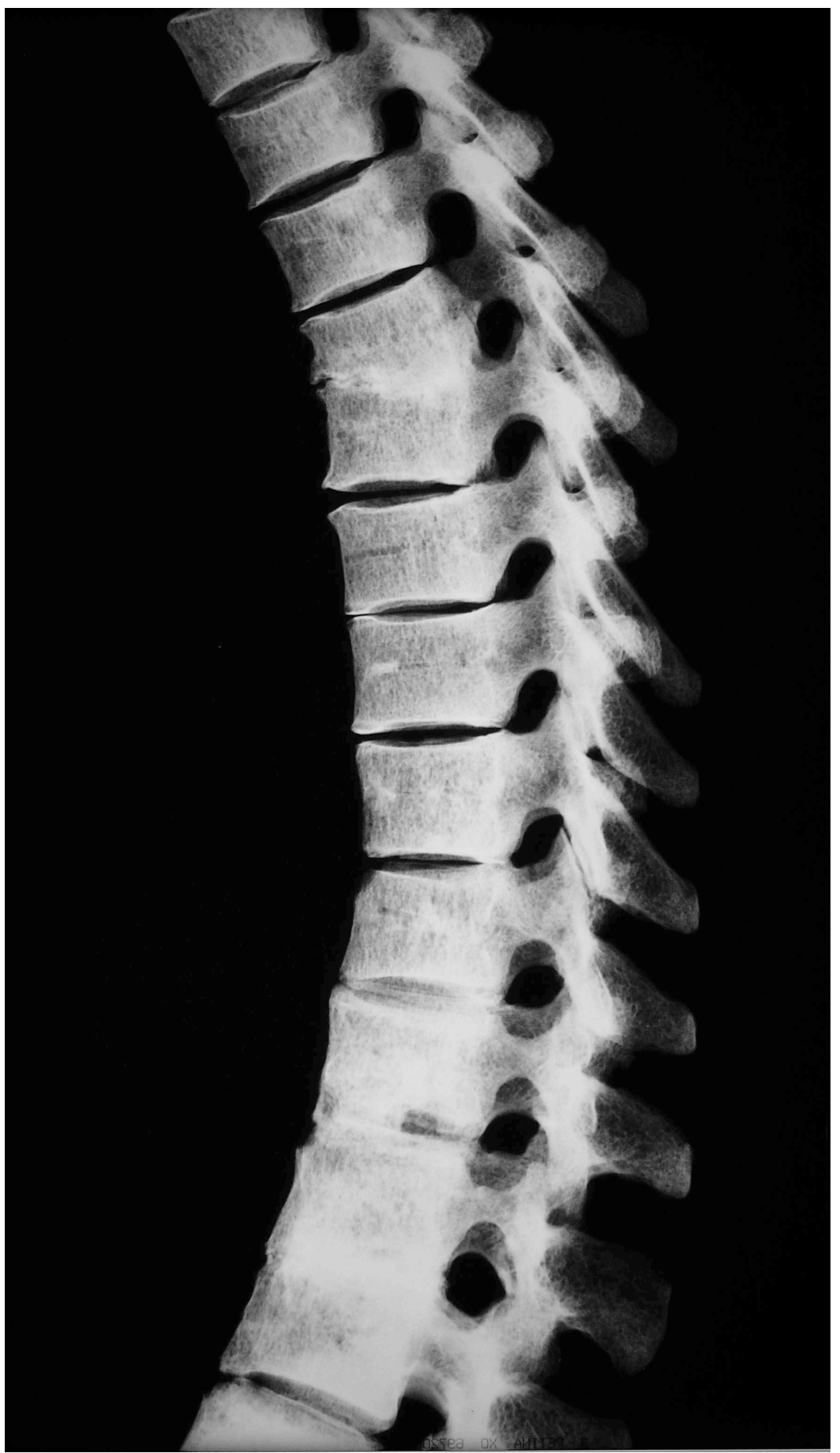

4 Figure 10 Radiograph shows the fusion of Th7-8 and L1-3

5 (Zalavár-Vársziget-Hadrianus templom, female, Grave No.: 39/02) 


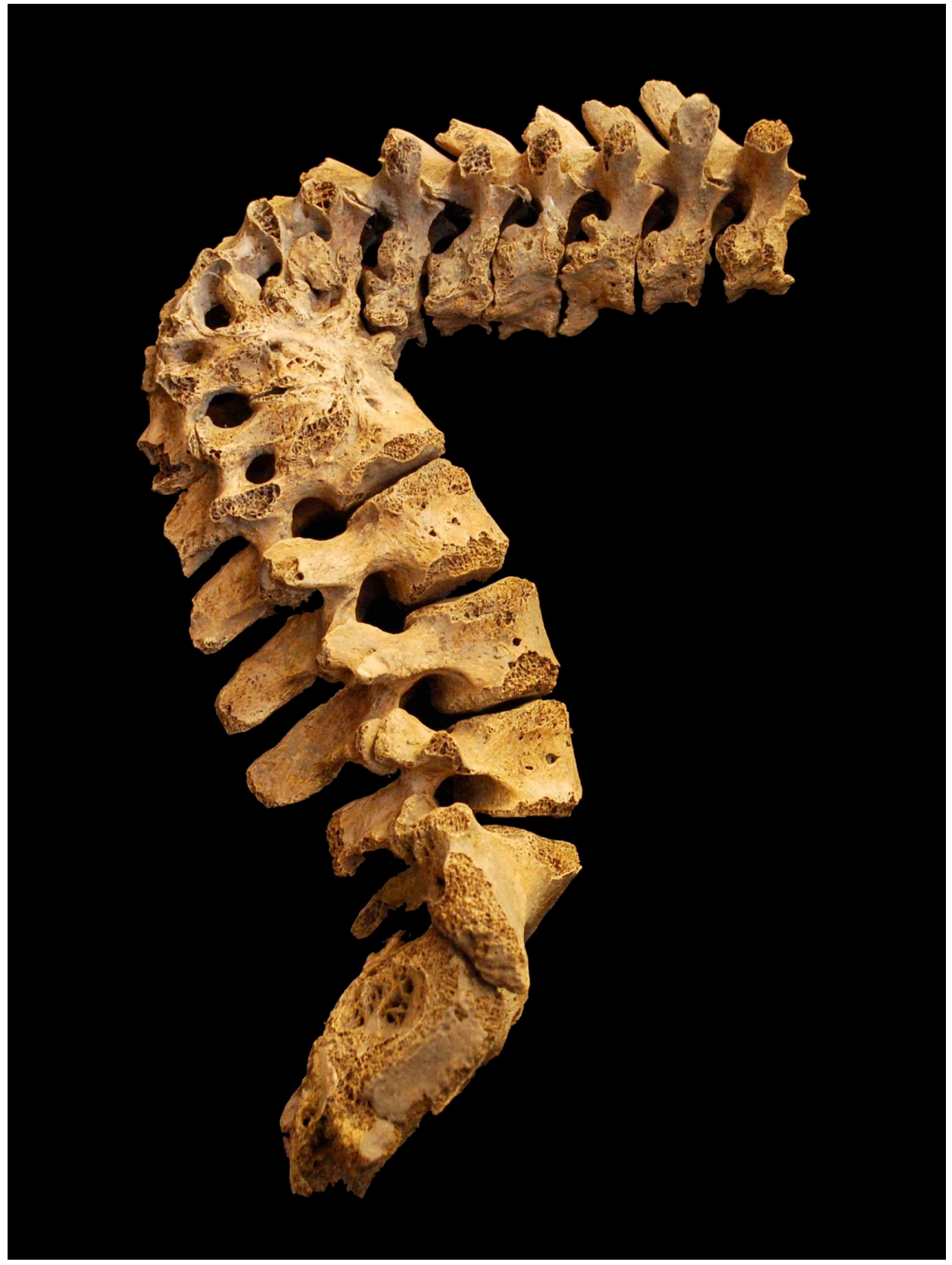

4 Figure 11 Pott's disease, angular kyphosis in Th8-L2

5 (Zalavár-Vársziget-Kápolna, juvenile, Grave No.: 17/03) 


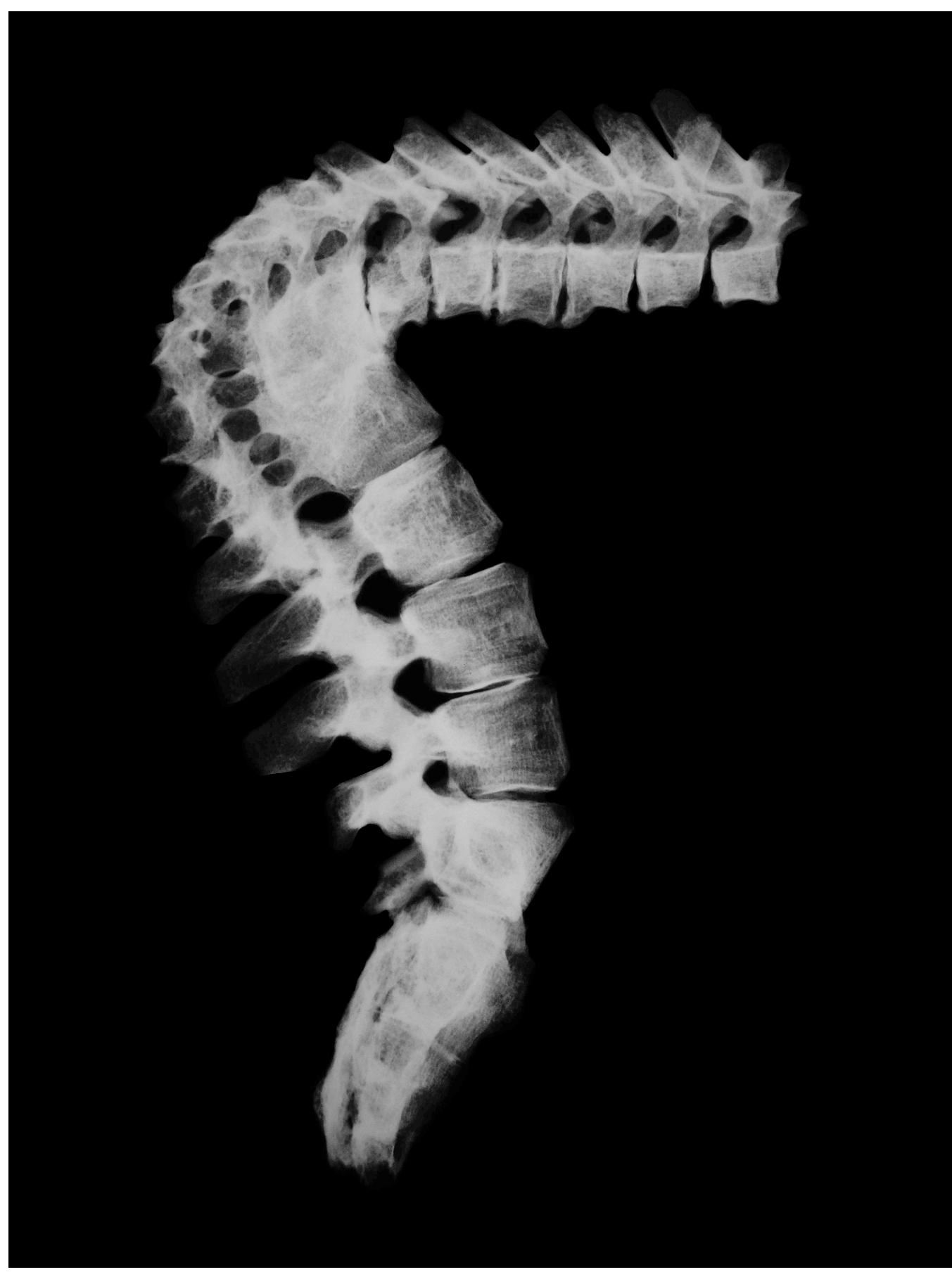

4 Figure 12 Radiograph shows Pott's disease; angular kyphosis with osteosclerosis in Th8-L2 5 (Zalavár-Vársziget-Kápolna, juvenile, Grave 17/03) 


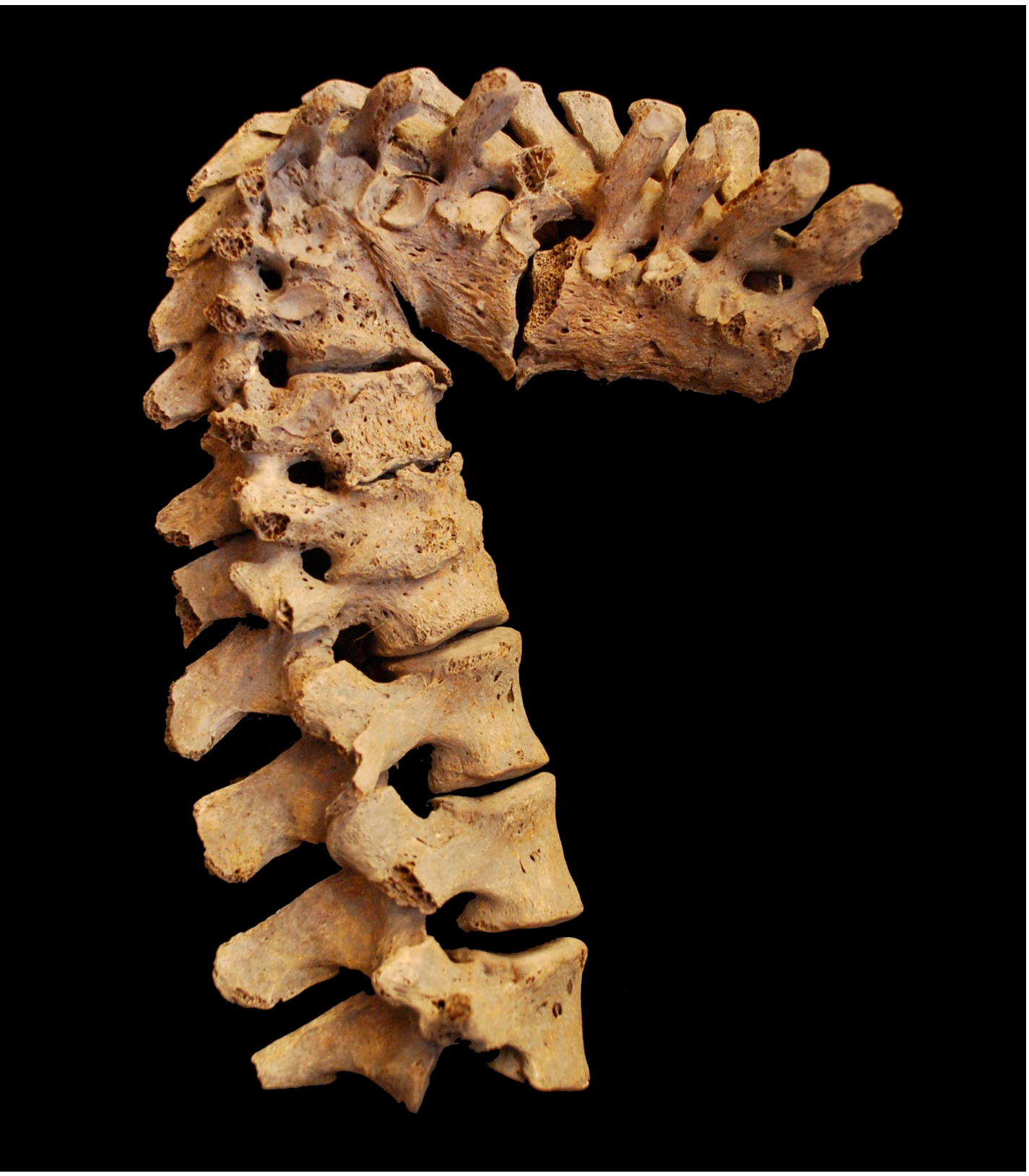

5 Figure 13 Pott's disease; angular kyphosis in Th8-10, and three fused vertebral „blocks” (Th1-4,

6 Th5-11, Th12-L2)

7 (Zalavár-Vársziget-Kápolna, juvenile, Grave No.: 32/02) 


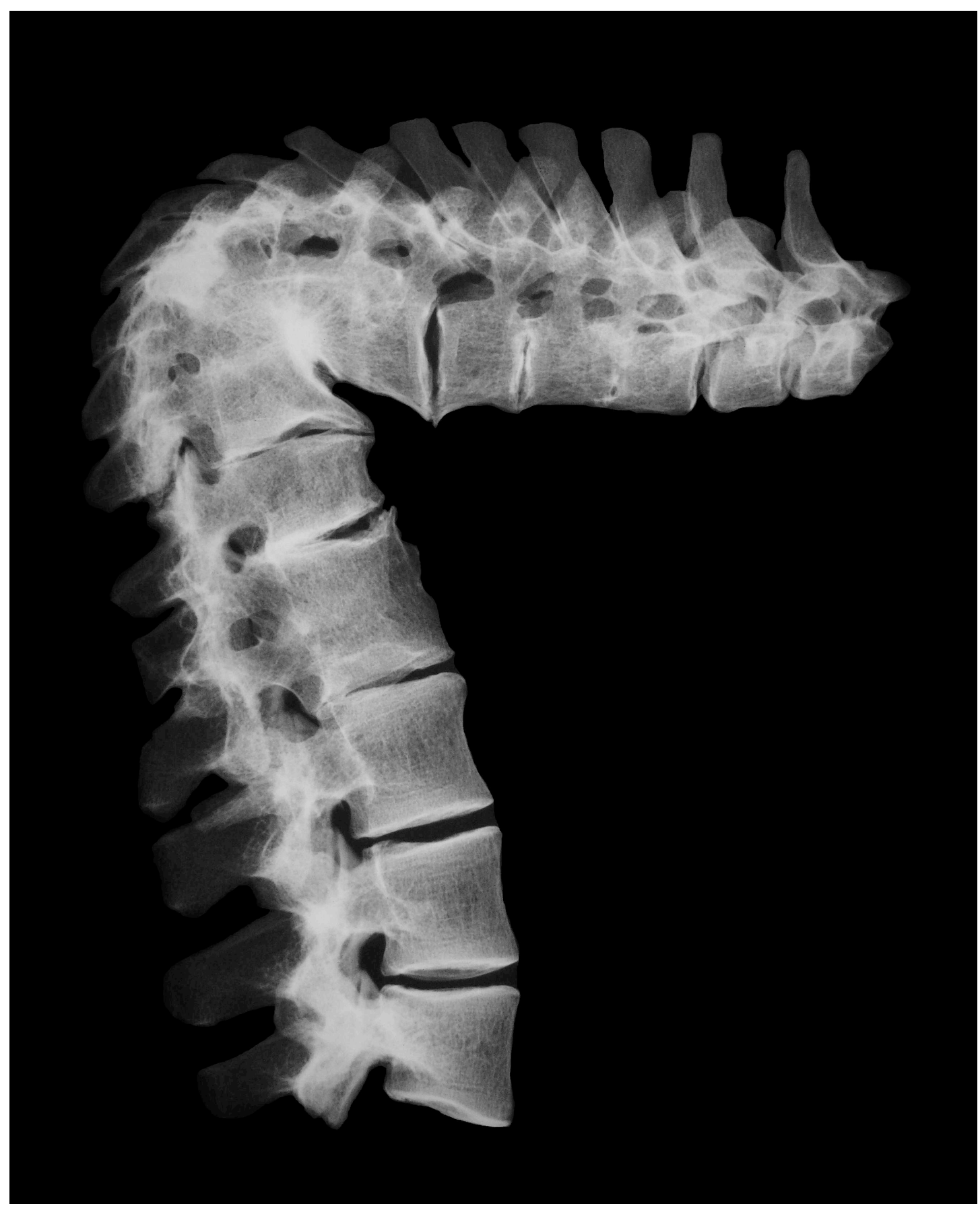

4 Figure 14 Radiograph shows Pott's disease, angular kyphosis in the thoracic region

5 (Zalavár-Vársziget-Kápolna, juvenile, Grave No.: 32/02) 


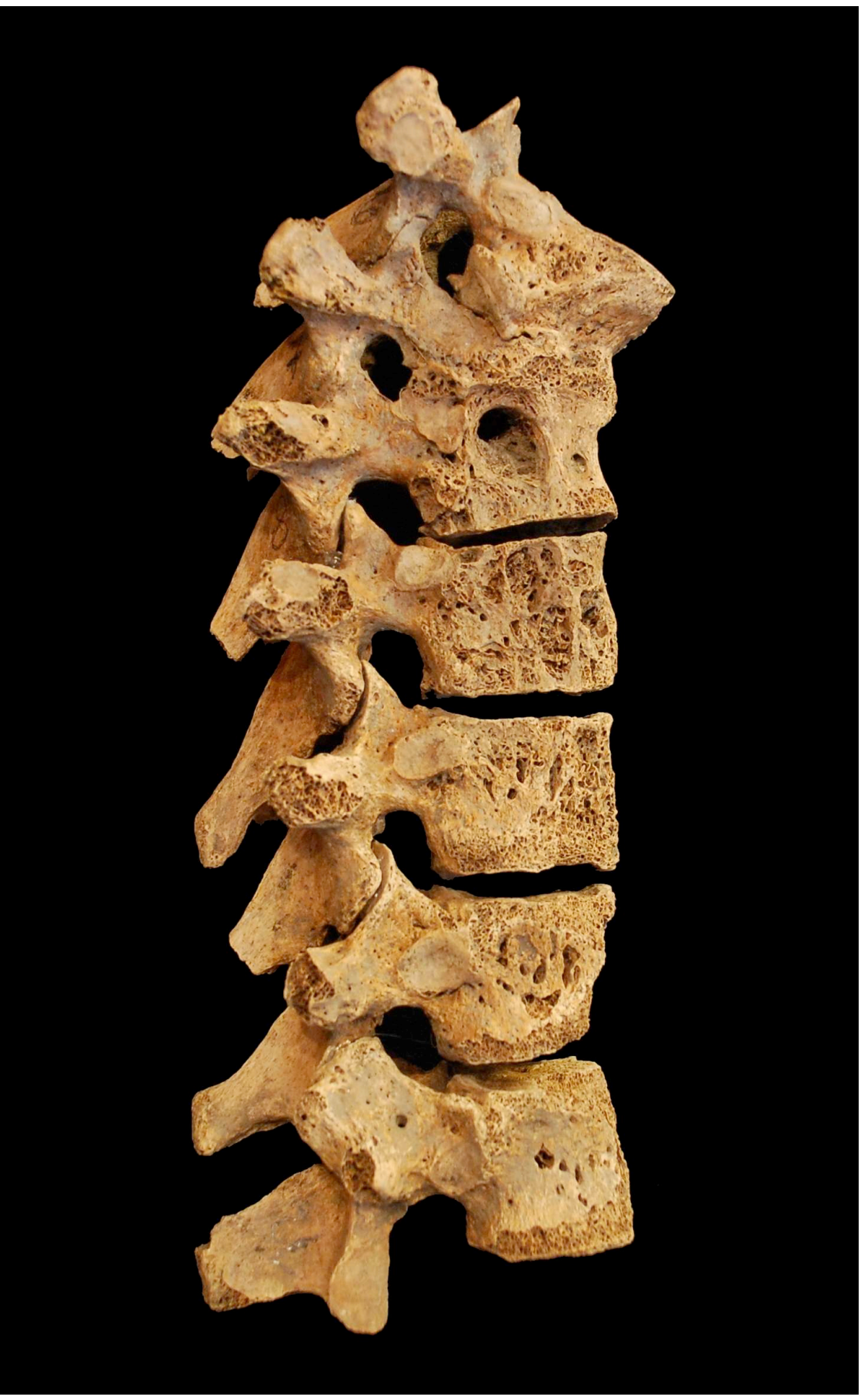

5 Figure 15 Spinal tuberculosis, lateral view, fusion of vertebrae (Th6-8) with slight gibbus,

6 cavities and traces of cold abscess

7 (Zalavár-Vársziget-Kápolna, juvenile, Grave No.: 74/03) 


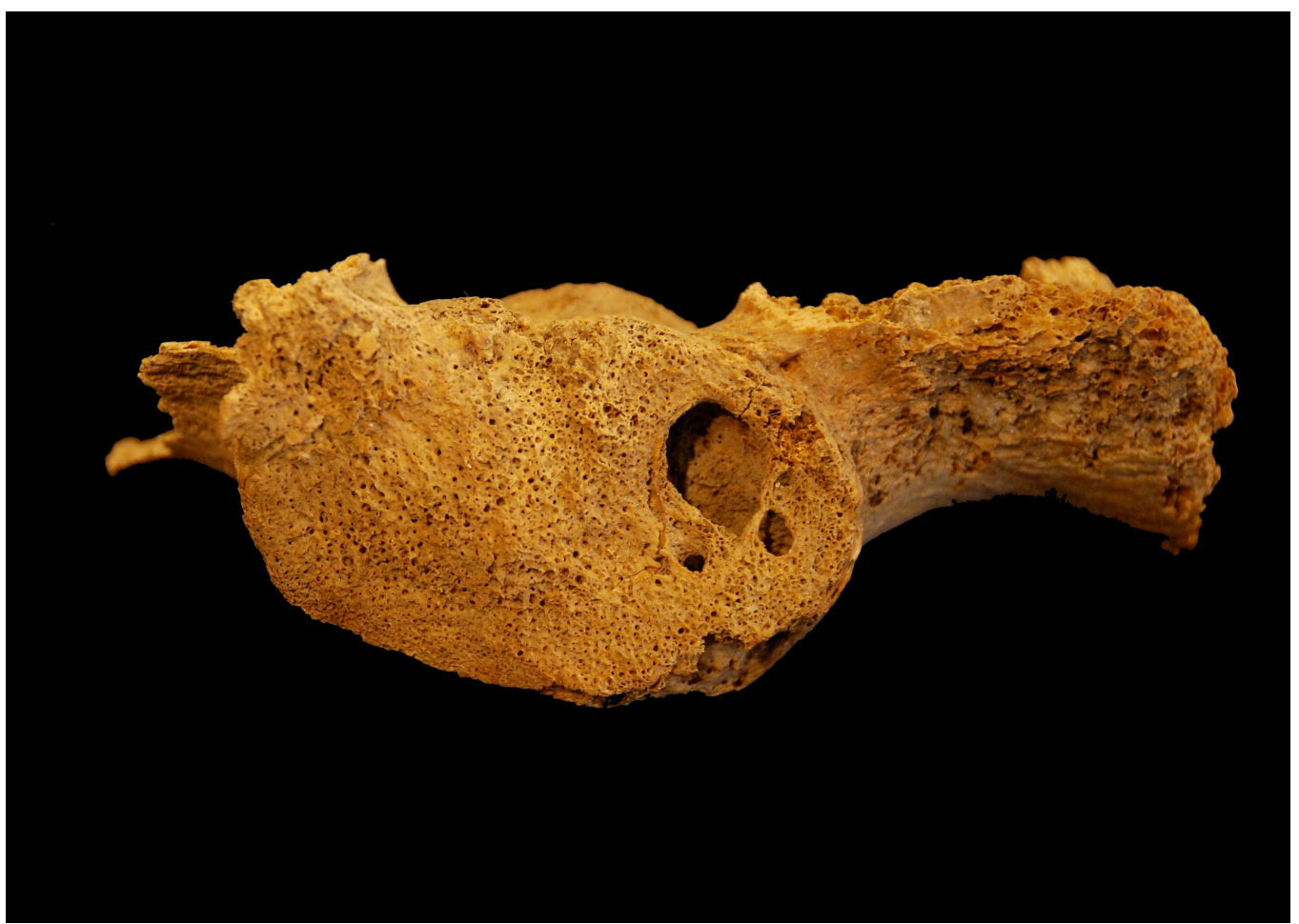

10 Figure 16 Lumbosacral tuberculosis with erosion and cavities

11 (Zsámbék, premontrei templom, female, Grave No.: 161)

12

13

14

15

16

17

18

19 


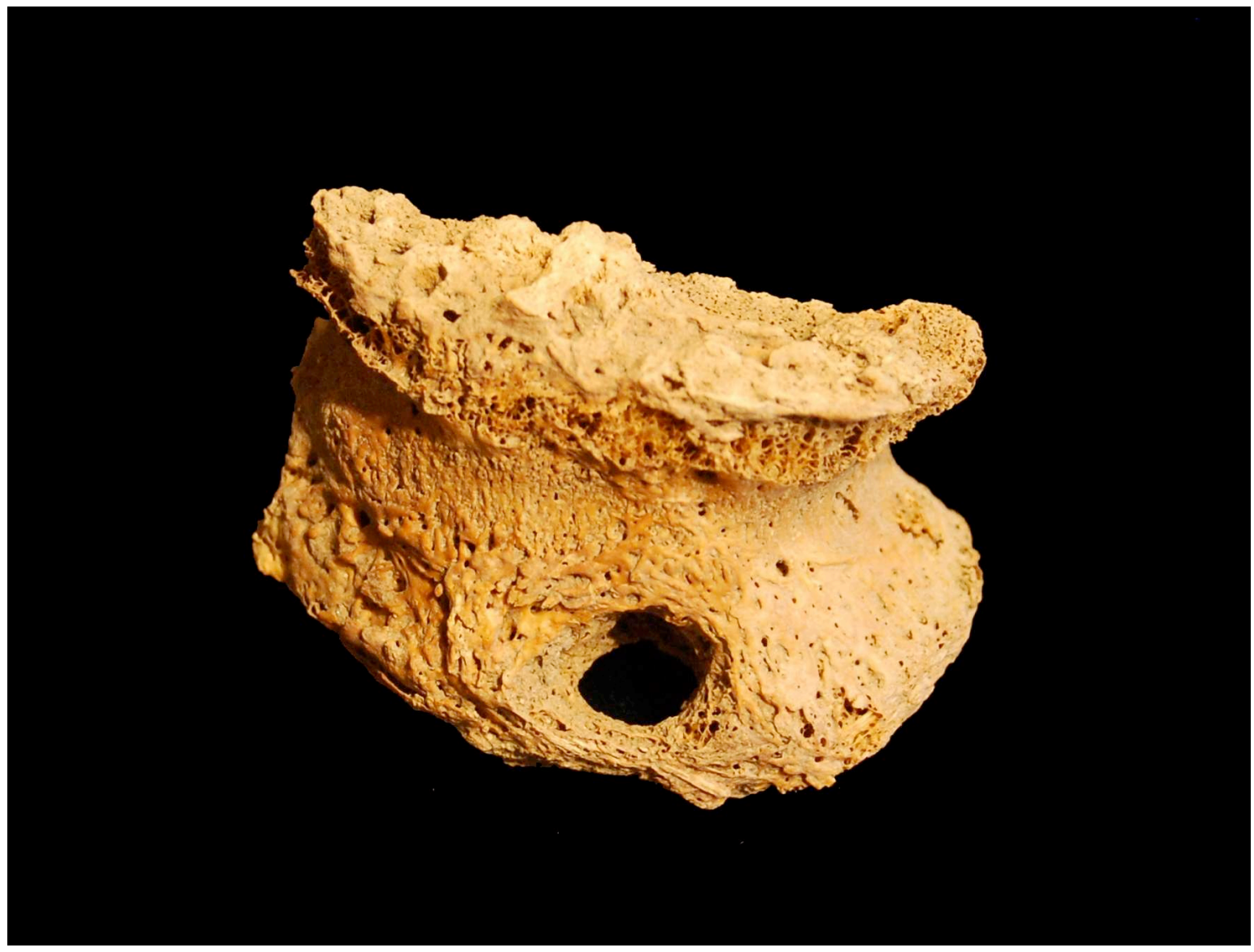

8 Figure 17 Lumbosacral tuberculosis with erosion and cavities in the L4

9 (Zsámbék, premontrei templom, female, Grave No.: 161) 


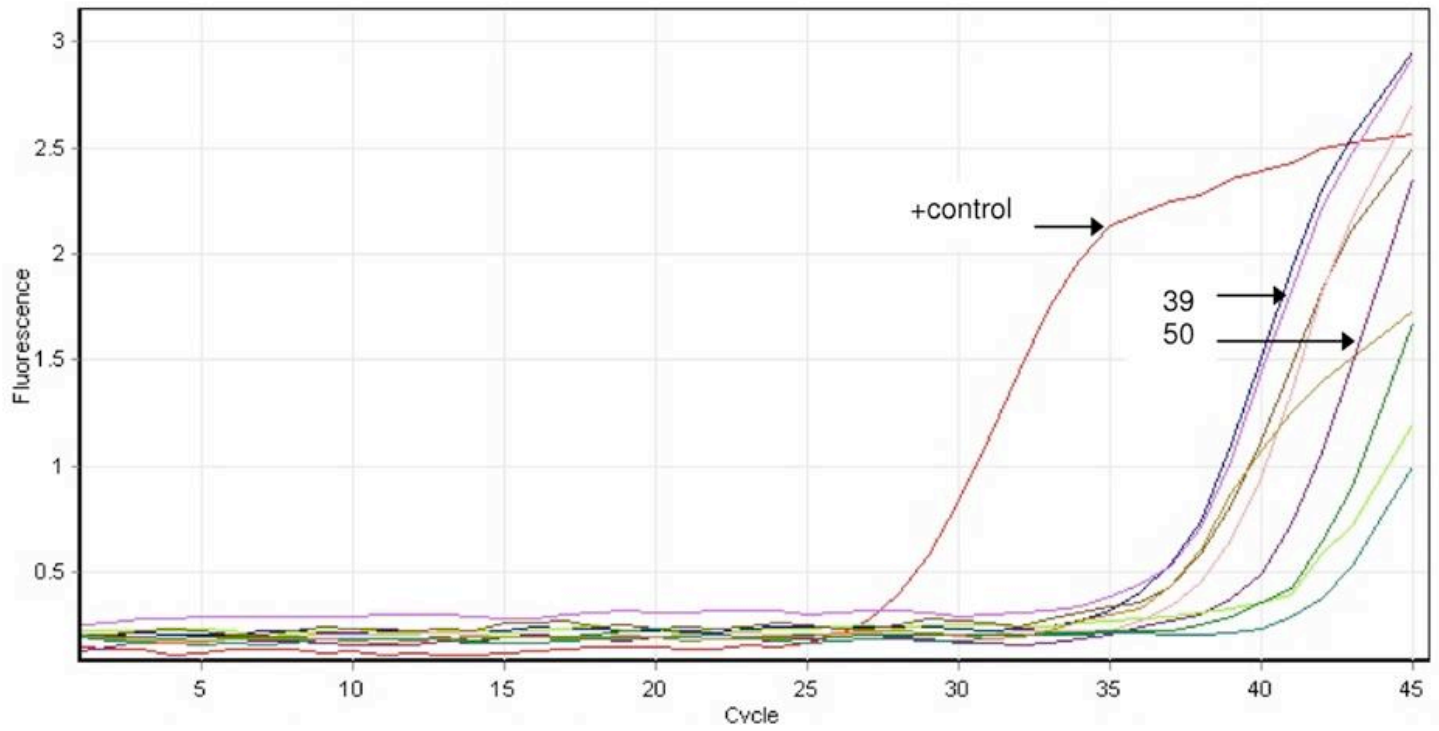

5 Figure 18 Real-time PCR of archaeological samples using IS1081 primers.

6

7

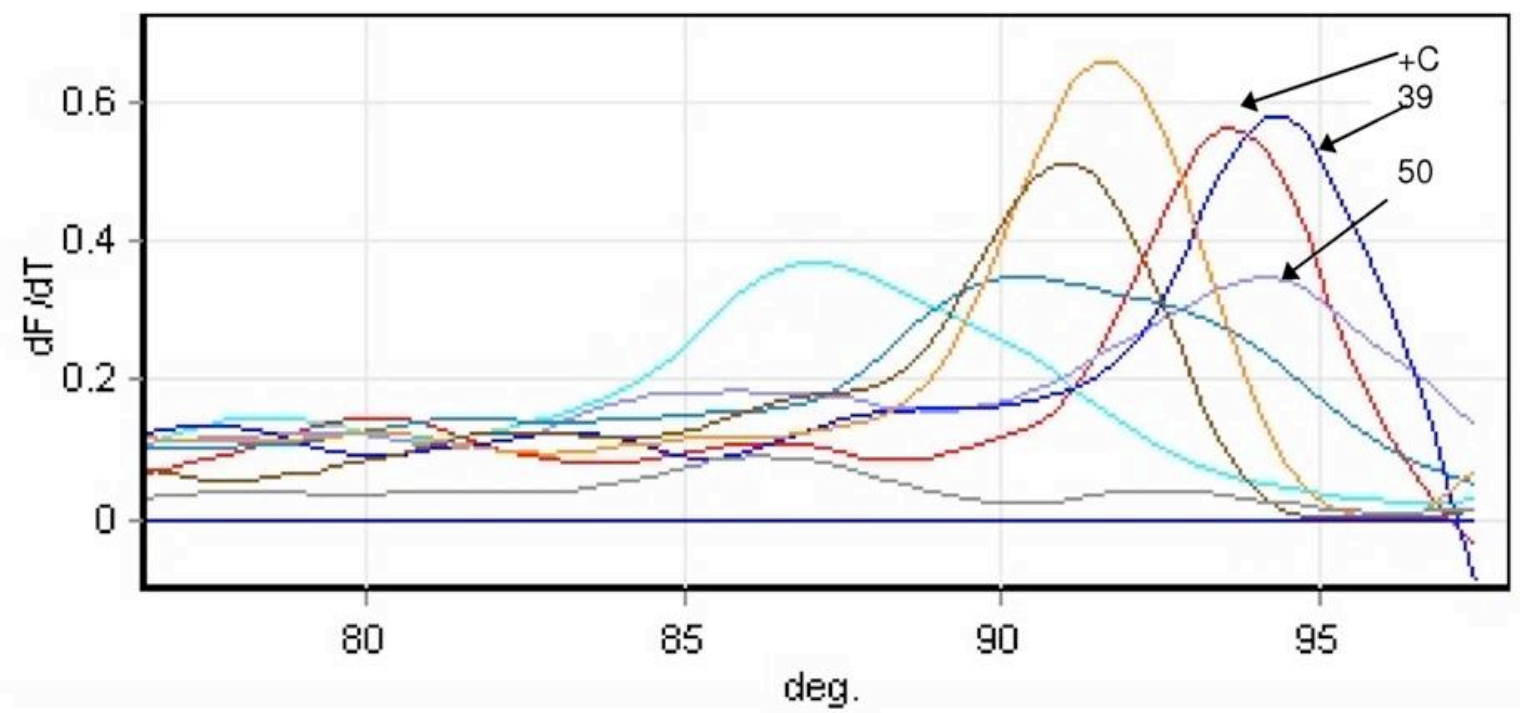

10 Figure 19 Melt analysis of Real-time PCR products

11

12 


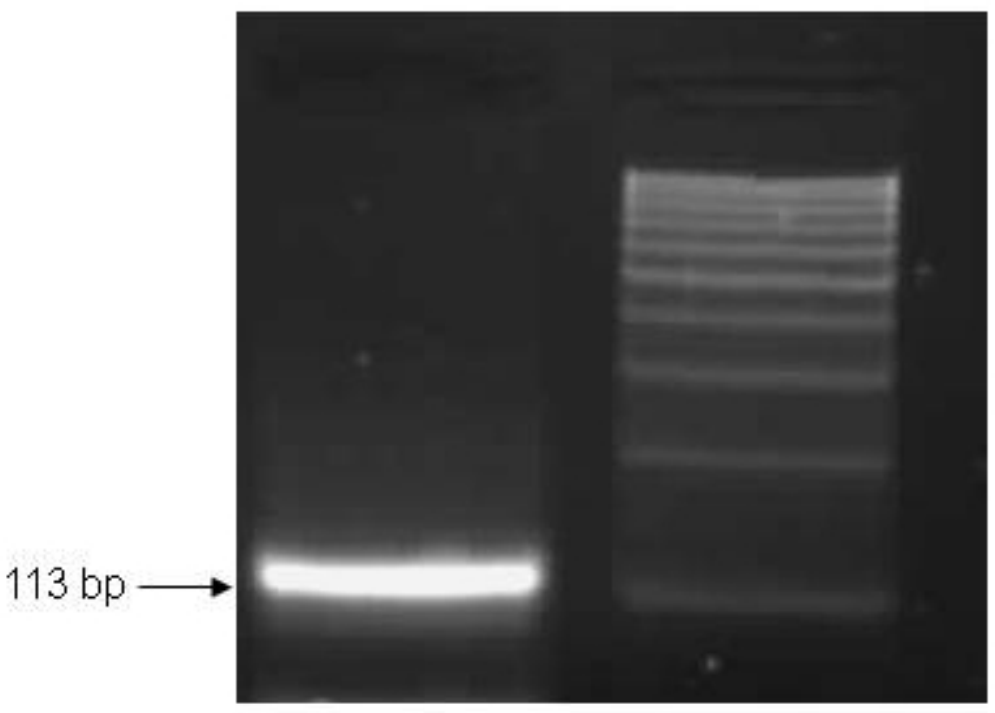

11

12 Figure $20 \mathrm{Gel}$ of purified IS1081 PCR product from sample 50/01 with molecular markers

13 (bright line on the left indicates the $113 \mathrm{bp}$ PCR product)

14

15

16

17

18

19

20

21 


\section{Reverse sequence}

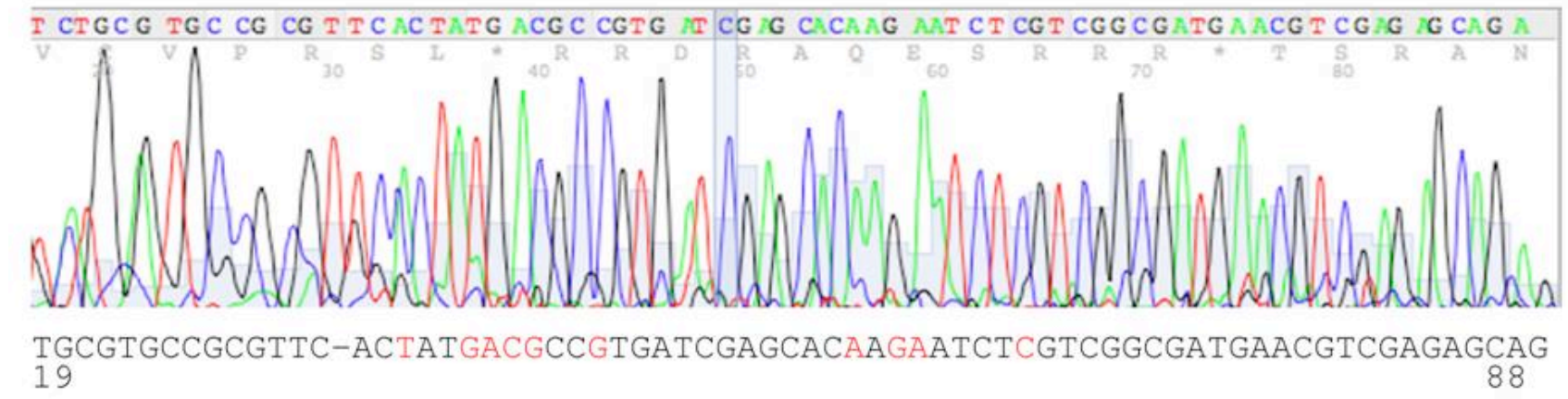

4

5 Figure 21 Partial DNA sequences from IS1081 PCR products from sample 39/02 and 50/01

\section{Reverse sequence}

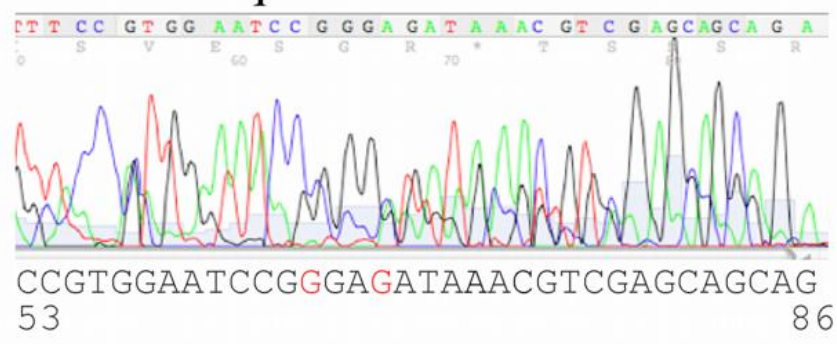

$$
53
$$

11 Figure 22 Partial DNA sequences from IS1081 PCR products from sample 50/01

12

13

14

15

16

17

18 
Quantitation data for Cycling A.Green

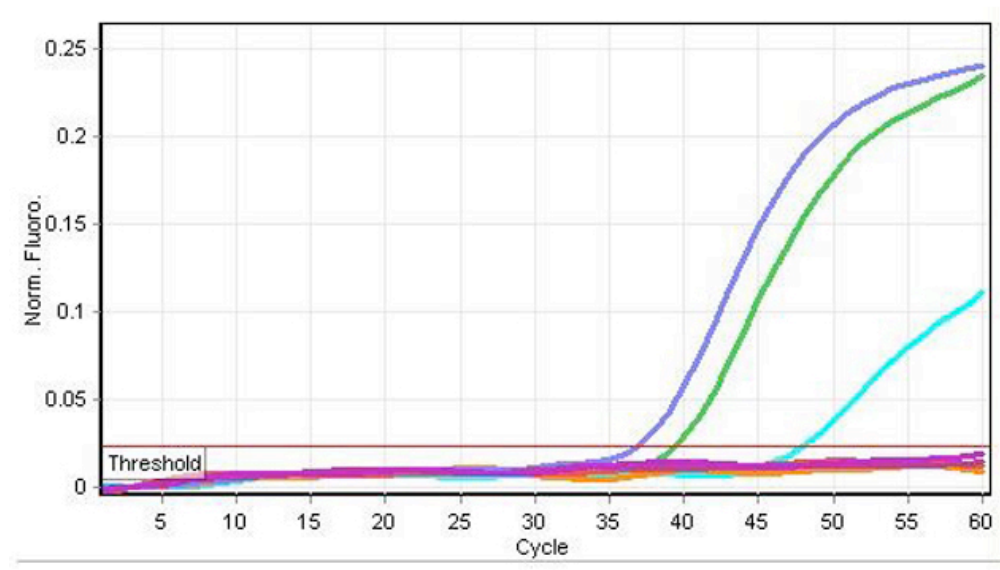

\begin{tabular}{|l|c|l|l|l|l|l|l|}
\hline \multicolumn{7}{|l|}{ No. Colour Name Type Ct } & Given Conc (copies/ul) Calc Conc (copies/ul) \% Var \\
\hline 5 & & 32 & Unknown & 39.46 & & & \\
\hline 7 & & 39 & Unknown & 48.09 & & & \\
\hline 9 & & wb1 & NTC & & & & \\
\hline
\end{tabular}

(Continued on next page)...

\begin{tabular}{|l|c|l|l|l|l|l|l|}
\hline \multicolumn{6}{|c|}{ No. Colour Name Type } & Ct & Given Conc (copies/ul) Calc Conc (copies/ul) \% Var \\
\hline 14 & & 74 & Unknown & 37.02 & & & \\
\hline 18 & & wb2 & NTC & & & & \\
\hline 27 & & wb3 & NTC & & & & \\
\hline 31 & & EC & Negative Control & & & & \\
\hline
\end{tabular}

$3 \quad$ Figure 23 Real time PCR with IS6110 probe and primers showing cycling and cycle thresholds from samples 74/03, 39/02, 32/02 with negative extraction and PCR controls 